University of Texas at El Paso

\title{
DigitalCommons@UTEP
}

Open Access Theses \& Dissertations

2012-01-01

\section{The Effects of Defendant and Juror Language Use on Sentencing Recommendations}

Victoria Christine Estrada

University of Texas at El Paso, vcestrada@miners.utep.edu

Follow this and additional works at: https://digitalcommons.utep.edu/open_etd

Part of the Criminology Commons, $\underline{\text { Criminology and Criminal Justice Commons, Law }}$ Commons, and the Psychology Commons

\section{Recommended Citation}

Estrada, Victoria Christine, "The Effects of Defendant and Juror Language Use on Sentencing Recommendations" (2012). Open Access Theses \& Dissertations. 2084.

https://digitalcommons.utep.edu/open_etd/2084

This is brought to you for free and open access by DigitalCommons@UTEP. It has been accepted for inclusion in Open Access Theses \& Dissertations by an authorized administrator of DigitalCommons@UTEP. For more information, please contact lweber@utep.edu. 


\title{
THE EFFECTS OF DEFENDANT AND JUROR \\ LANGUAGE USE ON SENTENCING \\ RECOMMENDATIONS
}

\author{
VICTORIA CHRISTINE ESTRADA \\ Department of Psychology
}

APPROVED:

Harmon M. Hosch, Ph.D., Chair

James M. Wood, Ph.D

Jennifer L. Eno Louden, Ph.D.

Jon Amastae, Ph.D.

Benjamin C. Flores, Ph.D.

Interim Dean of the Graduate School 


\section{Copyright (C)}

by

Victoria Christine Estrada

2012 


\section{Dedication}

For my parents, David and Irma Estradathrough your sacrifice and love, I have realized my dreams.

For my sister, Vanessa Estrada, and my partner, Frank Magañayour support has helped me conquer more than I thought possible. 


\title{
THE EFFECTS OF DEFENDANT AND JUROR \\ LANGUAGE USE ON SENTENCING RECOMMENDATIONS
}

\author{
by \\ VICTORIA CHRISTINE ESTRADA, B.A.
}

\section{THESIS}

Presented to the Faculty of the Graduate School of The University of Texas at El Paso

$$
\begin{aligned}
& \text { in Partial Fulfillment } \\
& \text { of the Requirements } \\
& \text { for the Degree of }
\end{aligned}
$$

MASTER OF ARTS

Department of Psychology

THE UNIVERSITY OF TEXAS AT EL PASO

August 2012 


\section{Acknowledgements}

I would like to than my advisor, Dr. Harmon M. Hosch, for his tremendous support and guidance for the past two years, and for the motivation to pursue a doctoral degree. I would also like to thank my committee members, Dr. James M. Wood, Dr. Jennifer A. Eno Louden, and Dr. Jon Amastae for their feedback and assistance toward this research.

Additionally, I would like to thank my colleagues, Dr. Larissa Schmersal, Mosi Dane'el, Tamara Kang, and Jessica Armendariz for their gracious comments, encouragement, and support throughout this process.

Finally, I would like to thank my parents, David and Irma Estrada, my sister, Vanessa Estrada, and my partner, Frank Magaña. Thank you for always believing in my abilities, encouraging my goals, and for your endless support. 


\begin{abstract}
Spanish-language testimony is an extra-legal variable not widely studied in the legal psychology field. More emphasis has been placed on the translation of the testimony as well as accent attitudes. The current study extended research conducted by Stephan and Stephan (1986) to investigate the impact of Spanish-speaking defendants and mock-juror's language use and proficiency on sentencing recommendations. Two hundred and seventy-seven participants from the University of Texas at El Paso read a case vignette of a first-degree aggravated assault and asked were asked to provide sentence recommendations for the defendant. The defendant's testimony was presented in English or Spanish with an English translation, and mock jurors were asked items to assess their English and Spanish language use and proficiency. It was hypothesized that (1) Spanish-speaking defendants would receive harsher sentences, (2) mock jurors high in Spanish proficiency would be more lenient overall, and (3) Spanish-speaking defendants would receive more lenient sentences as Spanish use and proficiency of the participant increased. The results found no significant effects for defendant language, mock-juror language use, or the interaction of the two. However, a significant interaction of mock-juror Spanish proficiency and defendant language was found. Contrary to what had been predicted, it was found that mock jurors high in Spanish proficiency gave more lenient sentence recommendations to English-speaking defendants. As an explanation for this unexpected finding, I hypothesize that Spanish-speaking defendants are experiencing the black-sheep effect (Marques, Yzerbyt, \& Leyens, 1988), where individuals are more punitive toward in-group members to protect the positive identity of the group. This speculation should be confirmed through replication in future studies.
\end{abstract}




\section{Table of Contents}

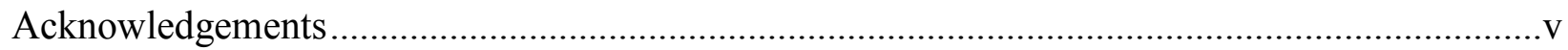

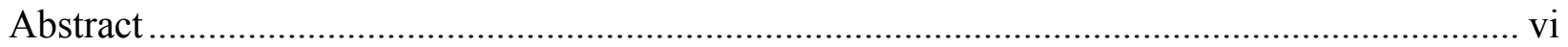

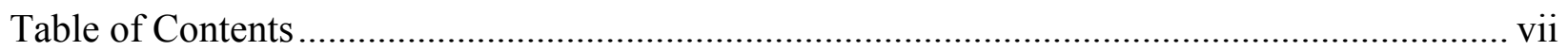

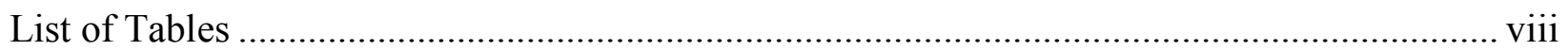

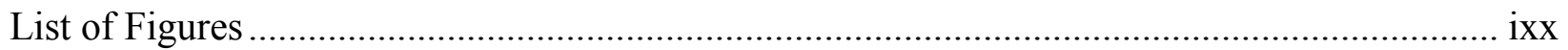

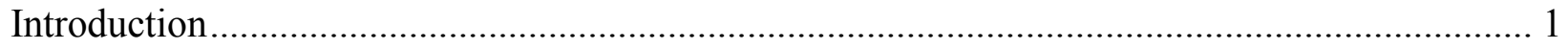

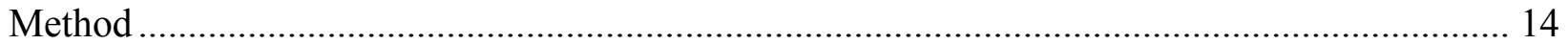

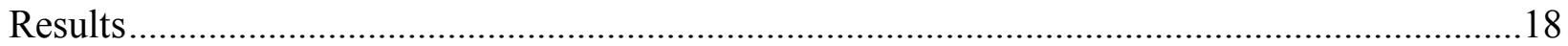

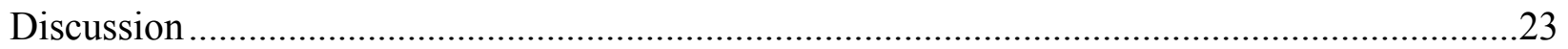

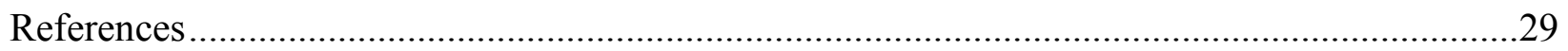

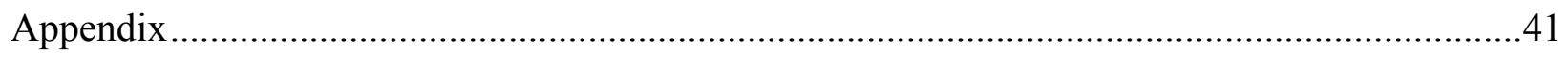

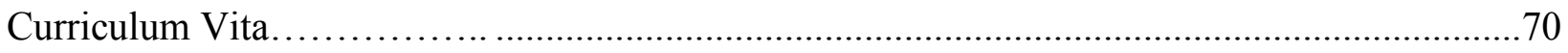




\section{List of Tables}

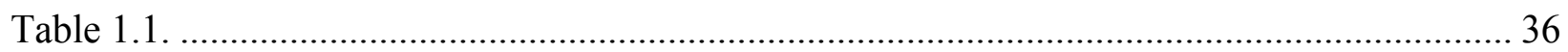

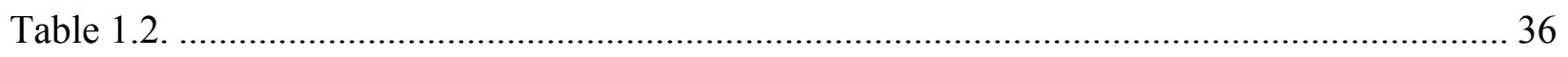

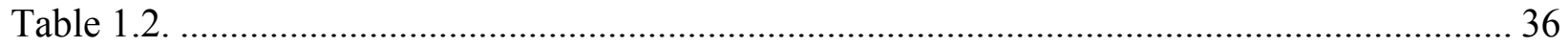

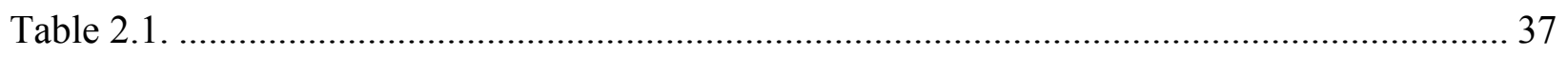

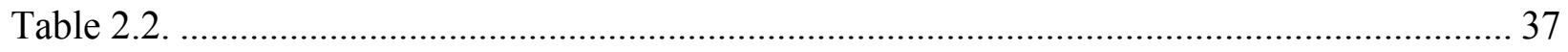

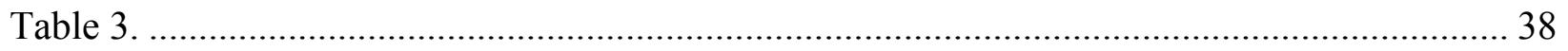

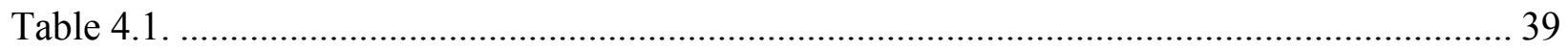

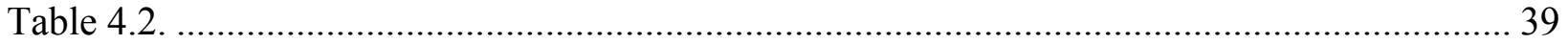

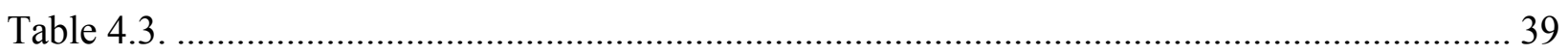




\section{List of Figures}

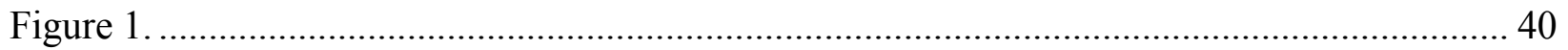




\section{Introduction}

Individuals of Hispanic ${ }^{1}$ origin make up the largest and fastest growing minority in the United States. According to the U.S. Census, the proportion of people living in the United States who reported being Hispanic was at $16.3 \%$ by 2010, surpassing African Americans as the largest minority in the United States by 3.7\% (U.S. Census Bureau, 2010). In 2009, 76\% of Hispanics reported speaking Spanish in their home, with over 50\% stating that they do not fully understand English (U.S. Census Bureau, 2009). The Bureau of Prisons reports that, as of December 2011, approximately $34.6 \%$ of inmates are Hispanic, which is double the proportion in the U.S. population (Bureau of Prisons, 2011). Because of this rapidly growing population, and given the disproportionate number of Hispanics within the criminal justice system, there are unique language complications in the judicial system. The federal court recognized the growing need for interpretation of foreign language in the courtroom, and introduced the Court Interpreters Act in 1978.

\section{The Court Interpreters Act}

Prior to the federal court passing the Court Interpreters Act in 1978, the United States did not have any law to guarantee the right to an interpreter in the event that a person did not speak or understand English, or for individuals with hearing and speech impairments. Although this act is specifically for federal proceedings, it guarantees that an interpreter will be provided in any criminal or civil matter to a defendant or witness in the event that the individual "(1) speaks only or primarily a language other than the English language; or (2) suffers from a hearing impairment (whether or not suffering also from a speech impairment)" (Court Interpreters Act,

\footnotetext{
${ }^{1}$ The term Hispanic is used to include individuals of Mexican, Puerto Rican, Cuban, Central, or South American origin.
} 
1978, p. 412-413). An interpreter is granted if this language barrier impedes understanding of the court proceedings or communication with an attorney.

The judge is given the authority to grant an interpreter. In civil cases, the judge also determines who will incur the cost of the interpreter, whether it is the court, both parties, or either of the parties alone; interpreters in civil courts are not guaranteed (Berk-Seligson, 1990).

Many states have modeled their own use of interpreters in the courtroom after the federal Court Interpreters Act (Berk-Seligson, 1990). For example, the state of Texas will provide an interpreter in civil and criminal proceedings if it is requested by either party or by a witness (Licensed Court Interpreters Law, 2011). At the federal level, the interpreters are required to be certified if they are to be employed as federal interpreters. In an expert panel on Community Interpreter Testing and Certification, William Hewitt, Principal Court Research Consultant for the National Center for State Courts, reported that approximately $4 \%$ to $5 \%$ of individuals who attempt the federal court interpreter certification examination pass both the written and oral sections. Approximately 20\% pass the initial written section of the exam (Expert Panel on Community Interpreter Testing and Certification, 2007). At the federal level, interpreters are held to very high standards of language translation proficiency to become federally certified, but at the state level, the requirement for certification varies. Because the states do not have a national exam of their own, the standards of language translation may vary greatly, potentially altering the translation of testimony in the courtroom.

\section{Language Use in the Courtroom}

Because Hispanics are the largest minority group in the United States, it can be expected that the most common language that is interpreted in the judicial system is Spanish. Over 120 languages were used in court proceedings in 2010 that required translation, and a total of 
357,171 interpretation "events" took place in U.S. District Courts (Annual Report of the Director, 2010). Any occasion where a translator was requested in the courtroom for a witness or defendant was recorded and reported as an interpretation event. Spanish language interpretation comprised $96.6 \%$ of those interpretation events, underscoring the importance of the current study's focus on Spanish use and interpretation in the courtroom. Because Texas is a state that borders Mexico and has a large Hispanic population, we can expect the number of Spanish language interpretation events to be even higher.

Several problems with interpretation in courts have been examined within the last few decades. Many researchers are concerned that the interpretation of a witness's testimony may affect the length and style of the speech, which can affect the juror's perception of the testimony (e.g., Berk-Seligson, 1987; Bradac, 1990). Berk-Seligson (1987) specifically looked at Spanishto-English translation of court interpreters and found that they change the testimony in subtle, but linguistically significant ways. The researcher identified several different speech styles that exist, and how each was used by attorneys to make an individual on the stand appear more or less negative to the jury.

Speech styles. O'Barr (1982) described differences between narrative and fragmented styles of speech, and attorneys may use techniques to elicit this style from the witness they question on the stand. The narrative style is characterized by full and detailed responses from witness testimony. By contrast, the fragmented style is characterized by abbreviated and concise replies from the witness. Both styles have been used strategically by attorneys in the courtroom. Attorneys assume that narrative testimony is viewed more favorably than fragmented testimony; thus, attorneys will try to elicit narrative style responses from their witnesses and try to limit responses to fragmented testimony from opposing witnesses (O'Barr, 1982). This highlights the 
effect that speech can have on the jury of the courtroom, and how witnesses can be viewed as more or less believable based on their delivery of the testimony. Aside from attorneys manipulating speech styles of testimony, an official courtroom translator can translate statements and alter the speech style in a similar fashion.

O’Barr also identified differences between powerless and powerful styles of speech. The powerless style is characteristic of witnesses who use intensifiers (which amplify the meaning of a word) or hedges (which reduce the effect of a statement, hesitations), are polite, and ask the attorney questions. Powerful testimony is a style that does not use any of the elements described above in the powerless testimony. It has been shown that these two styles of testimony can elicit different responses in the receiver of their message. In a study conducted by Erickson, Lind, Johnson, and O'Barr (1978), 152 participants listened to witness testimony in either the powerless or powerful style, while the overall content of the testimony remained the same. Individuals who heard the powerful style testimony rated the witness as significantly more credible and attractive, as compared to those who heard the powerless testimony style.

Similar results have been found when witnesses provide testimony simply with the absence of hesitations and hedges. Mendoza, Hosch, Ponder, and Carillo (2000) presented mockjurors with testimony of a prosecutorial witness in either English or Spanish with an English interpretation. Hesitations and hedges were either present or absent in both the interpreter and witness's testimony in the Spanish language condition. The researchers found a main effect of witness hedges and hesitation, such that when the prosecution's witness did not hesitate or hedge, mock jurors convicted the defendant at a higher rate compared to the condition in which hesitations and hedges were present. 
Berk-Seligson (1987) noted that the court interpreter, in addition to altering speech style, can subtly lengthen the translated testimony of the witness. By doing so, the interpreter transforms the testimony into a powerless style of speech. According to Berk-Seligson (1987), when one translates English into Spanish, the Spanish version tends to be longer than the English version. However, this did not occur in the quantitative analysis of witness testimony translations by six court interpreters (Berk-Seligson, 1987). In 24 of the 27 individual witness testimony events reported in the quantitative analysis, the English translation was significantly longer than the original Spanish testimony, which was contrary to expectations. Upon closer examination of the testimony, it was discovered that the court interpreter began adding elements of the powerless style into their translation of the Spanish testimony. For example, one interpreter inserted a hesitation and hedge in the translation into English:

Attorney: Approximately how many?

Interpreter: ¿Aproximadamente cuántos?

Witness: Un promedio de veintiuno.

Interpreter: Uh, probably an average of twenty-one people (Berk-Seligson, 1987, p. 1107).

The italicized words were added by the interpreter, and the actual translation was "An average of twenty-one" (p.1107). In this translation, "both the hesitation form and the hedge serve to make the answer less sure, less definite, and the witness less strongly committed to his affirmation" (Berk-Seligson, 1987, p. 1107). Again, the study demonstrates the power of language styles on the impressions of witnesses in the courtroom. It is important to continue research of language use in the courtroom to identify any potential biases that may influence credibility of witnesses and decisions made by jurors. 
More recently, Lee (2011) found similar discrepancies in Korean to English translations. Interpreters in the courtroom setting failed to capture the style of speech of the witness. Interpreters face many difficulties when translating testimony, such as processing oral information in a quick and efficient manner, and consistently producing accurate interpretations of the testimony. Additionally, the interpreter's own speech style may be inserted into the final translation (Lee, 2011). Other important features of speech content may become lost during the translation. The interpreter has limited "contextual" information, compared to the witness who is providing a first-hand report of the events, and this may potentially affect the court interpreter's translation of the statement (Lee, 2009).

Language accent attitudes. More broadly, several studies have focused their attention on individual's perception of accented or non-native English relative to the participants' perception of their native language (Brennan \& Brennan, 1981; Dailey, Giles, \& Jansma, 2004; Lev-Ari \& Keysar, 2010; Lindemann, 2005; Lippi-Green, 1994; Ryan \& Carranza, 1975). People listening to accented speech (relative to their native language) are capable of altering their own accent, explained by the speech-accommodation theory (Giles, 1973). Giles terms the act of individuals changing their own accent in response to another accent mobility. Individuals may decide to distance or associate themselves from the individual speaking with an accent that is not of their native language (sender) due to social motivations, also known as divergence and convergence, respectively. Individuals who voluntarily alter their accents are also evaluating the sender. Those who diverge and move away from the sender's accent perceive that individual negatively, and those who perform convergence perceive the sender more positively (Giles, 1973). 
In the legal context, the jury listens to witness testimony and may evaluate witnesses based on their accent. This is an example of characteristics of witnesses or defendants that may affect juror's decisions. Previous studies have examined juror's verdicts and sentencing recommendation as a function of defendant characteristics, such as defendant and victim gender (Pozzulo, Dempsey, Maeder, \& Allen, 2010), defendant race (Bucolo \& Cohn, 2010; Espinoza \& Willis-Esqueda, 2008; ForsterLee, ForsterLee, Horowitz, \& King, 2006), and defendant language use (Stephan \& Stephan, 1986). Language use in the courtroom has not been systematically tested for its potential effects on juror decision-making, and it is important that we investigate this topic further, especially regarding Spanish-language use.

The context in which we speak may also affect individual's preference for accented or standard English speakers. For example, Ryan and Carranza (1975) asked participants to rate individuals on four tape recordings. One set of recordings was a dialogue between mother and son in a home setting, which was read by three individuals who spoke non-accented English (relative to Spanish), and another three individuals who spoke in Spanish-accented English. A second set of recordings was made in a similar way, but the dialogue consisted of a teacher giving a history lesson. Non-accented English speakers were rated more favorably in both the home and school context. Upon further analyses, they also found that Anglo participants rated Spanish-accented English lower than Mexican American or African American participants. Ryan and Carranza expected Mexican American participants to rate Spanish-accented English more favorable on solidarity scales, which measured similarity between the speaker and receiver. However, they found no differences among those ratings. One potential explanation for this null finding may be that Mexican Americans are exposed to more accented English, therefore they do 
not have more positive or negative feelings toward either Spanish-accented or non-accented English.

Similarly, Brennan and Brennan (1981) researched the relationship between varying degrees of accented English and evaluations of the speaker. They found differences among scores evaluating the speaker as the accent differed. Overall, the speakers with a lower degree of Spanish accent received higher status ratings, and solidarity ratings remained moderate across the levels of accent.

Accent can be an indicator of the geographic or social area an individual is from, as well as an indication of their native language (Lippi-Green, 1994). The assumptions made from an individual's accented target language may create biases that translate into negative or positive judgments made about that individual. Lippi-Green argued that an accent that is highly related to race, ethnicity, and culture of minorities may create accent discrimination based on how well the speaker can communicate and the "goodwill" of the individual listening. This discrimination can be further explained by Milroy and Milroy’s (1999) standard language ideology, where an individual's belief that there is a standard type of language creates a bias for that specific standard and leaves no room for variability in that language.

Dailey et al. (2004) demonstrated further examples of accent discrimination. Nonaccented speakers, as compared to Spanish-accented speakers, were rated more positively on items such as competence, although Hispanic participants did not rate the non-accented speakers as high as the Anglo participants did. Levi-Ari and Keysar (2010) examined the truthfulness of accented English as well as whether the degree of accent (i.e., mild or heavy) had an effect on the truthfulness ratings. Participants were asked to rate the truthfulness of trivia questions, and were told "that the speakers were only reciting what the experimenter wrote" (p. 1094) so the 
truthfulness rating would be a result of the difficulty in understanding the accent. They found that, overall, both levels of Spanish-accented English were rated less truthful than standard English, leading researchers to conclude that, because the listener had difficulty understanding the speaker, they reacted by rating the statement as less truthful (Levi-Ari \& Keysar, 2010).

As mentioned earlier, accented speech may serve as a cue to a person's geographic/social location, ethnicity, or race, and those listening to this accented speech may categorize the speaker as being part of a group based on the evaluation of the accent. The speaker may be classified as being part of an in-group or out-group, and based on this categorization, one may have a more positive or negative evaluation of that person.

\section{Social Identity Theory and Defendant-Juror Similarity}

The differences between Hispanic and non-Hispanic participants' ratings of accented English in studies such as Dailey et al. (2004) may be explained by the similarity-leniency hypothesis proposed by Kerr, Hymes, Anderson, and Weathers (1995). According to this hypothesis, the greater the perceived similarity between the defendant and juror, the more lenient the juror's decision is for the defendant, thus voting in favor of an in-group member or providing the in-group member with a more lenient sentence recommendation. This in-group membership may be established by characteristics such as race (Abwender \& Hough, 2001; Forsterlee et al., 2006) and language use (Stephan \& Stephan, 1986).

The similarity-leniency hypothesis is more broadly supported by the social identity theory proposed by Tajfel and Turner (1979). Individuals favor others who are apart of the same in-group, which can be defined by race, socioeconomic status, gender, etc. It is then possible that the more similar juror's language use is to the language used by the defendant in court, they may 
classify the defendant as an in-group member. This may result in more lenient sentencing recommendations for the defendant.

In order for in-group or out-group categorization to be achieved, Tajfel and Turner (1979) argue that people must identify themselves as being a part of that group and recognize it as part of their self-concept. In other words, although others may categorize an individual as belonging to a group, the person must self-identify as belonging to this group. According to social identity theory, we are motivated to maintain positive group identities, and differentiate ourselves from out-groups. In order to do so, we treat in-group members more favorably (in-group favoritism) while discriminating against out-group members (out-group bias), thus creating distance between the groups.

Tajfel (1970) has also established that group discrimination can be created under minimal circumstances explained by the minimal group paradigm. Tajfel (1970) administered a "dotestimation task" to participants and asked them to estimate the number of dots they saw when the stimulus was displayed. Regardless of their actual estimation of dots, the researchers informed participants that they were either over- or under-estimators of dots. They were also informed of the other participant's classification (over- or under-estimators). When given the opportunity to award money to individuals, the participants would award more money to others who were part of their group and less to the out-group. Similar results have been obtained using dot estimation and art preference tasks (DiDonato, Ullrich, \& Krueger, 2011).

Because groups may be created under minimal circumstances, language may serve as a characteristic for inclusion or exclusion in a group. Little research has been conducted focusing on language as a distinct characteristic that could create an in-group/out-group situation (De la Riva, 2012; Stephan \& Stephan, 1986). Some may argue that language is a factor or ethnicity, 
and serves as a reminder of ethnic identity as well as maintaining differences with an out-group (Giles, Bourhis, \& Taylor, 1977). However, an unpublished dissertation conducted at the University of Texas at El Paso found evidence of out-group favoritism for ethnicity, but outgroup discrimination for language among the same group of individuals (De la Riva, 2012). Using implicit measures, De la Riva (2012) found that Mexican-Nationals (Spanish-dominant speakers) demonstrated out-group bias in relation to language: when Mexican-Nationals were presented with English or Spanish primes, there was an out-group bias, with higher association between negative targets and English primes. However, when the same group was presented with photographs of Anglo-American or Mexican ethnicities, there was a higher association between positive primes and Anglo-American targets than with Mexican targets (out-group favoritism). These findings demonstrate the potential separation of language as a component of ethnic identity. The Mexican Nationals group in De la Riva's (2012) study had more positive associations with Spanish and Anglo-Americans which are not congruent with one another.

\section{Overview of the Present Study}

There have been mixed results in the jury-decision making literature regarding Spanish language use and an in-group/out-group effect. Some research suggests that Spanish language use by the defendant has a negative impact on verdicts (Hosch, Daudistel, Holmes, \& Graves, 1991; Stephan \& Stephan, 1986) while Spanish used by a prosecutorial witness had no impact on juror's decisions (Mendoza et al., 2000).

Extending the research conducted by Stephan and Stephan (1986), this study was designed to explore the effects of Spanish language use in U.S. courtrooms on jurors' sentencing recommendations and perceptions of the defendant. Specifically, the present study examines 
whether mock juror sentencing recommendations varied as a function of the language spoken by the defendant and the juror's own self-reported language use.

\section{Hypotheses}

Hypothesis 1. In Stephan \& Stephan's (1986) second study, a main effect for defendant language was found, where a Thai-speaking defendant was convicted more often than the English-speaking defendant. Further, because English is the unofficial language of the U.S., a Spanish-speaking defendant may be seen as an out-group member, therefore they may be punished more severely than the English-speaking defendant. A significant effect for defendant language is expected to replicate these findings, where participants who are exposed to the Spanish testimony of the defendant will provide more severe sentences than those who read the case summary with the defendant's testimony in English only. I expect that their perceptions of the defendant would be more negative as well.

Hypothesis 2. I also expect to find a significant effect for mock juror's language use, in that as jurors reported using Spanish more frequently in their daily lives, sentence recommendation (in years) will decrease. Participants in this condition will also perceive the defendant more favorably. A previous study conducted at the University of Texas at El Paso found that Hispanic mock-jurors were more lenient in sentencing recommendations overall than Anglo-American mock-jurors, regardless of defendant ethnicity, so I expect that these finding will be replicated (Perez, Hosch, Ponder, \& Trejo, 1993).

Hypothesis 3. Finally, I expected an interaction between the mock juror's language preference and the language used by the defendant. Specifically, mock jurors who report using Spanish more frequently in their daily lives would give Spanish-speaking defendants more

lenient sentences. As the similarity between the defendant and mock-juror increases, therefore, 
according to the similarity-leniency hypothesis, the defendant will receive more lenient sentences than the English-speaking defendant. That is, I expected to obtain an interaction effect on sentence length. 


\section{Method}

\section{Participants}

Two hundred and ninety six students at the University of Texas at El Paso participated in this study. Nineteen participants were excluded from analyses because they failed a manipulation check or did not complete a majority of the dependent measures. Participants were recruited through the Psychology research participation system (SONA), and received course credit for their participation in the study. The demographics of the sample resembled that of the population they came from, with $63.2 \%$ of participants being female, $82.3 \%$ of Hispanic origin, and a mean age of 20.9 years. Eighty-nine percent of the sample reported being U.S. citizens ${ }^{2}$.

\section{Procedure}

The study compared defendant language use (Spanish or English) and language use of the juror as they influenced sentencing recommendations. The dependent variables were individual mock juror's sentencing recommendations and a ten-item scale measuring perceptions of the defendant. Participants were randomly assigned to one of two conditions, and I used hierarchical linear regression for data analysis.

Participants completed the study online. Once they signed up to complete the experiment, participants were e-mailed a website and instructed to complete the study at one time.

Participants were asked to read a consent form (Appendix A) and to provide an electronic signature prior to completing the study. They then completed a voir dire questionnaire. Once completed, the participants read a case vignette of a first-degree aggravated assault case and provided their sentencing recommendations. Following the recommendations, they were asked

\footnotetext{
${ }^{2}$ Individuals who did not meet criteria to serve as a juror were retained in the current analyses to increase power. Additional analyses were conducted and revealed no significant differences between jury eligible and non-jury eligible participants.
} 
several questions as a manipulation check, and provided responses to a Likert-type defendant perception scale. They were then asked to complete the Los Angeles Epidemiologic Catchment Area (LAECA) acculturation scale, developed by Burnham, Telles, Karno, Hough, and Escobar (1987) as well as a self-report language proficiency scale developed by Dr. Wendy Francis at the University of Texas at El Paso. Lastly, responses from a law enforcement attitude scale were recorded, and the participants acknowledged a debriefing page.

\section{Materials}

Voir dire questionnaire. The voir dire questionnaire (Appendix B) asked participants to provide basic demographic information and other relevant material (e.g., previous jury experience, history of victimization, etc.) to determine jury duty qualification and to identify any biases that may affect their sentencing recommendations.

Trial summary. Participants read a case vignette (Appendix C) describing an aggravated assault of a police officer. Because the focus of the study is concerned with mock jurors' sentencing recommendations, participants were informed that the defendant was found guilty of the crime, and they were being asked to recommend a sentence by a group of attorneys who approached the researchers for assistance. In the case vignette, the defendant was pulled over for a routine traffic violation. Upon running his information through the police database, the officer discovers that the defendant had a warrant out for his arrest due to unpaid traffic violation tickets. As the police officer explains his findings to the defendant, the defendant becomes angry and attacks the officer, breaking his nose. The officer requests another unit to assist him, and they arrest the defendant. The defendant's testimony is presented in the case vignette.

Participants who were randomly assigned to the English defendant language condition read the defendant's testimony in English. Those who were randomly assigned to the Spanish 
defendant language condition read the defendant's testimony in Spanish as well as the interpretation into English by the courtroom interpreter. Due to no significant effects found in evaluations of courtroom interpreters (Mendoza et al., 2000), it has been suggested that bilingual jurors attend to the original testimony in Spanish and rely on their own translation, as opposed to reading both English and Spanish versions of the testimony. Further, if monolingual English speakers read both versions of testimony, one can assume that they do not understand the Spanish account of testimony thus diminishing the possibility of potential confounds with displaying testimony twice in the Spanish-speaking defendant condition.

Following the guidelines of back-translation outlined by Brislin (1986), the original English testimony of the defendant was translated into Spanish by a bilingual research assistant, and translated back into English by a second bilingual research assistant. The two English versions were compared and discrepancies were discussed and resolved to capture the message of the testimony.

Sentencing guidelines and additional measures. Participants were provided with sentencing guidelines for a first-degree aggravated assault and were asked to recommend the defendant's sentence (Appendix D). The sentencing guidelines required the mock jurors to recommend a prison sentence between five and 99 years, and an optional fine not exceeding $\$ 10,000$. The mock jurors were then given a set of multiple choice and free response questions regarding the facts of the case to assess their knowledge of the relevant facts and as a manipulation check. They also provided a percentage ranging from 0 to 100 , indicating the defendant's perceived guilt, as well as responses to determine the mock juror's perception of the defendant (Appendix E). The items asked mock jurors to rate how intelligent, friendly, trustworthy, interesting, considerate, hard-working, competent, likeable, pleasant, and 
sophisticated they perceived the defendant to be. I used 10 items obtained from Stephan and Stephan's (1986) 12-item questionnaire to assess mock jurors' perception of the defendant. Participants then completed the 26-item LAECA acculturation scale (Appendix F) in order to assess their language use in a variety of contexts. Specifically, items 2, 3, and 6 through 14 of the LAECA were used to create a composite to assess language use of the mock juror. Each item was scored on a Likert-type scale ranging from 1 (Spanish mostly) to 5 (English mostly). An additional language proficiency measure was administered, and two composites for English and Spanish proficiency were used to capture mock juror's self-reported language proficiency (Appendix G). The items were on a 9-point scale, with one indicating "not literate/fluent" and 9 as "very literate/fluent." Last, participants were asked to complete a law enforcement measure developed by Weitzer and Tuch (2004) to control for any biases toward law enforcement officers (Appendix $\mathrm{H}$ ) and to acknowledge a debriefing page (Appendix I). 


\section{Results}

Missing data. Preliminary analysis revealed a significant amount of missing cases (i.e., approximately 61 composites could not be created if the participant missed one or more of the items that comprised the composite). To address this issue, imputation was performed using the imputation software NORM (Schafer, 1997).

Police attitudes. A potential confound exists within the case vignettes. The victim of the aggravated assault was a police officer. To control for any effects due to police perceptions, an item from the police attitudes questionnaire was added to block 1 ("In general, how satisfied or dissatisfied are you with the police department in your neighborhood?"). Weitzer \& Tuch (2004) reported in their research of police attitudes that personal experiences with the police was not a required variable to determine police evaluations, so the item above was selected as it is a more direct question about police satisfaction. This variable did not account for a significant amount of variance in the model, $F(3,271)=1.52, p=.211$.

Language use composite and sentencing. Overall, the mean for sentence was 7.25

years, $\mathrm{SD}=5.34$, however, the data were positively skewed. ${ }^{3}$ Principal component analysis using direct oblimin rotation was conducted on the 11 LAECA items to create a mock-juror language use predictor. As mentioned earlier, the items asked participants to report their language preference and use in a variety of contexts, such as language spoken with their parents, friends, coworkers, as well as what language they typically read in or watched TV. Each item was scored on a Likert-type scale ranging from 1 (Spanish mostly) to 5 (English mostly). The analysis revealed loadings above .759 (with the exception of the item "What language do you use when

\footnotetext{
${ }^{3}$ Initial investigation revealed that the sentencing in years was positively skewed. Square root and log transformations were performed to normalize the variable. However, analyses conducted with the transformations did not differ from the results of analyses using raw data. The following analyses reported are with the raw data.
} 
speaking to your coworkers?") on a single component and a mock juror language use composite was created. Further, the composite was centered and used as a predictor. The raw score composite ranged in values from 11 to 55, with a lower score indicating more Spanish language use, and a higher score indicating more English language use. Table 1.1 displays the means, standard deviations, and confidence intervals for the predictors and dependent variables used in the following models.

A hierarchical regression was conducted, with race/ethnicity and gender entered in block 1 as nuisance variables. Previous research on extra-legal variables affecting juror decisionmaking has found that the gender of the juror can affect verdicts as well as sentencing recommendations (Crowley, O’Callaghan, \& Ball, 1994; ForsterLee et al., 2006; Gabora, Spanos, \& Joab, 1993; Pozzulo et al., 2010). For this reason, gender was controlled for in the regression analyses. Ethnicity was included as a nuisance variable to account for it as a confounding variable. In block 2, language of the defendant (English or Spanish) and the mock juror language use composite were entered as predictors. A third variable was created and entered in the block to test the interaction between language use of the mock jurors and the language spoken by the defendant. The dependent variable was the prison sentence recommendation in years.

The results revealed no significant effects for the overall model on sentencing recommendations in years, $\mathrm{R}^{2}=.021, \Delta \mathrm{R}^{2}=.007 F(5,269)=1.15, p=.334$. The model summary containing the $\mathrm{R}^{2}$ change is reported in Table 1.2. Table 1.3 shows the unstandardized coefficients and $p$-values for each predictor in the model.

Language use composite and perceptions of defendant. An additional dependent measure was used to capture the mock juror's perception of the defendant as predicted by the 
language spoken by the defendant, mock-juror language use, and the interaction of the two. Ten items from Stephan and Stephan's (1986) study were administered to participants on a Likerttype scale ranging from one to nine. The items asked mock jurors to rate how intelligent, friendly, trustworthy, interesting, considerate, hard-working, competent, likeable, pleasant, and sophisticated they perceived the defendant to be. Principal component analysis was conducted using direct oblimin rotation and all items loaded on to a single factor, with loadings above .581 . A composite for perception of the defendant was created with a range of potential scores from 10 (e.g. "Interesting") to 90 (e.g. "Uninteresting"). The defendant perception composite was substituted in the previous hierarchical model as the dependent variable, with race/ethnicity and gender entered in to block 1 as nuisance variables. Overall, the mean for the defendant perception composite was $54.85, \mathrm{SD}=15.28$. Block 2 , again, contained defendant language, the mock-juror language use composite, and the interaction term as predictors. Analyses revealed no significant effects on perceptions of the defendant, $F(5,269)=0.81, p=.540$. The model summary containing the $\mathrm{R}^{2}$ change is reported in Table 2.1. Table 2.2 shows the unstandardized coefficients and $p$-values for each predictor in the model.

Self-report language proficiency composite. To investigate language further, language use as a predictor was substituted with two self-report language proficiency scales for English and Spanish. Participants answered eight items asking their level of proficiency in reading, writing, speaking, and speech comprehension of English and Spanish. The items were on a 9point scale, with one indicating "not literate/fluent" and 9 as "very literate/fluent." Principal component analysis revealed loadings on two components; the first four items loading on English proficiency and the last four loading on Spanish proficiency. All loadings were above .842. Two composites of the four English and Spanish items were created to capture English and 
Spanish proficiency of the mock-jurors. Correlational analysis was conducted on the previous predictor of mock-juror language use and the two new predictors of English and Spanish proficiency. They are reported in Table 3. Hierarchical regression analyses revealed a significant interaction between defendant language and Spanish proficiency, $B=-.185, p=.05$; although the overall model was not significant, $F(8,267)=1.88, p=.063$. The model summary containing the $\mathrm{R}^{2}$ change is reported in Table 4.1. Table 4.2 shows the unstandardized coefficient and $p$-value for the interaction predictor. An examination of the means revealed that sentencing recommendations were higher for English-speaking defendants as the Spanish proficiency scores of mock jurors decreased and lower for English-speaking defendants as the Spanish proficiency scores increased. Table 4.3 details the means for sentencing recommendations of mock jurors who read Spanish or English testimony, as well as whether they were high or low in Spanish proficiency. A median split on the Spanish proficiency measure was conducted after analyses to illustrate the differences between the groups.

Excluded data. Because the participants were told the defendant was previously found guilty of the crime, they were asked to indicate their level of belief in the defendant's guilt from $0 \%$ to $100 \%$. Additional analyses were conducted excluding participants who indicated a percentage below $80 \%$. This percentage was chosen based on current literature on juror's selfreported criteria for reasonable doubt (Dane, 1985; Dhami, 2008; Horowitz, 1997; Simon \& Mahan, 1971). The same analyses were conducted using the mock-juror language use, English proficiency, and Spanish proficiency composites, and defendant language as predictors of sentence in years and perception of the defendant.

Mock-juror language use and defendant language were entered into the model with the new exclusion criteria, and there were no significant effects on sentencing or perceptions of the 
defendant $F(2,201)=1.89, p=.073$. Similarly, when the English and Spanish proficiency composites were entered in the model as predictors, there were no significant effects for the overall model or the individual predictor terms. 


\section{Discussion and Future Directions}

The goal of the present study was to examine sentencing recommendations as they are influenced by the language the defendant speaks (English or Spanish) and the mock juror's own language use and self-reported proficiency in the two languages. It was expected that mock jurors who reported greater English language use and proficiency would give lower sentences to English-speaking defendants than to Spanish-speaking defendants. The results of the regression analyses did not support the hypotheses. Specifically, there were no differences in sentencing recommendations between individuals who read a trial summary of an English- or Spanishspeaking defendant, nor were there any differences associated with mock jurors' reported language use.

The null effects may be explained by a lack of salient group membership. Tajfel and Turner (1979) stated individuals must identify themselves as part of a group and recognize group membership as part of their self-concept. Because participants were not specifically told that they were part of a Spanish or English language preference group, the participants may not have thought that language was relevant in this context. These participants live on the U.S./Mexico border, so they are typically exposed to both English and Spanish. A Spanish-speaking defendant may not be grouped as being a monolingual English or Spanish speaker because it is a common occurrence for people in the region to speak one or the other language.

Although I attempted to categorize participants based on their language use and proficiency, they may have perceived themselves differently than the categories I developed based on language. Because language and ethnicity are difficult to separate, participants may have used language as a cue for ethnicity, and identified that ethnicity as their in-group. The majority of our participants were Hispanic, and because both the English- and Spanish-speaking 
defendants were Hispanic, the null results could be due to the fact that participants saw either of the defendants as part of their in-group.

Also, the non-significant results could be an indication that language is seen as a component of ethnicity, and not necessarily a grouping characteristic in its own right. Giles et al. (1977) argued that language was a component of ethnicity, and serves as a cue to what ethnicity a person is: language alone may not be sufficient for individuals to categorize themselves into a group. However, future studies including Hispanics from a region where there are less bilingual Spanish-speakers may help to determine whether language can be used to determine in-group membership. If people of the same ethnicity but of varying Spanish language use, proficiency, or preference are sampled, this may help determine if language can be used as a grouping characteristic.

Similarly, language use and proficiency are constructs that are difficult to separate. People who are proficient in a language are more likely to use that particular language, and conversely, those who use a language more often become more proficient in that language. In future studies, it may be useful to measure language use and proficiency as one construct. The composites of this particular study were moderate-to-highly correlated (see Table 3).

The majority of my participants reported being Hispanic. In Stephan and Stephan's (1986) original study, the composition of their participants was roughly half Hispanic and half non-Hispanic. This could explain the non-significant results for language use. Again, it is possible that language is used as a cue to ethnicity, and without a comparable out-group of nonHispanics, replication was not possible when using language use and proficiency as predictors. Approximately $71 \%$ of the current sample reported being bilingual in English and Spanish. In future studies, obtaining a sample of three groups of mock-jurors, those who are 
mostly English or Spanish speakers and a group of bilingual English-Spanish speakers, may provide more variability in language use between groups, as well as create more salient language groups. Those who are not exposed to Spanish-speaking defendants or individuals in general may find language a more salient characteristic to compare against their own social identity. However, it should be noted that monolingual Spanish speakers are only allowed to serve as jurors in the state of New Mexico and in Puerto Rico, so this would lower external validity if people who mostly spoke Spanish were allowed to participate. A sample with larger variability in ethnicity as well would prove to be beneficial in disentangling the argument of language as a social identity.

However, it should be noted that the Spanish translation of the defendant's testimony was conducted by bilingual research assistants whose native language is Spanish. Future studies should conduct a more rigorous back-translation using professional interpreters to ensure the quality of the translation. Participants may be judging the interpreter's ability to translate, and this could potentially affect the results of the study.

Contrary to expectations, an interaction between the self-report language proficiency score and defendant language revealed rather surprising results. Participants high in Spanish proficiency assigned lower sentences to English-speaking defendants, which seems counterintuitive to the social identity theory. Because this interaction was found only with the Spanish proficiency measure, one may hypothesize that those high in Spanish proficiency are a bilingual sample of the participants. Bilingual individuals may consider both English and Spanish as part of their self-concept or in-group (De la Riva, 2012), but this would not explain the preferential treatment of people high in Spanish proficiency toward the English-speaking defendant. 
An additional explanation for the interaction of Spanish language proficiency and defendant language is participants with higher Spanish proficiency may be more motivated to acculturate to U.S. customs, and create out-group favoritism by preferring English versus Spanish speakers. A supplementary question asking participants to indicate who they want to socially identify with in regards to language use could be added to determine what group they would classify as an in-group.

Further, a more plausible explanation for the significant interaction is provided by the black sheep effect (Marques, Yzerbyt, \& Leyens, 1988). With support from Social Identity Theory, the black sheep effect states that both positive and negative evaluations of in-group members are more extreme than those made of out-group members, which is dependent on the behavior of the individual being judged. For example, if a Hispanic defendant commits murder, Hispanic jurors are more likely to punish the defendant more severely than a non-Hispanic defendant to preserve the positive identity of the in-group, because of the severity of the crime. In the current study, jurors were told that the defendant was found guilty of the crime. Those high in Spanish proficiency may have been motivated to preserve the group's positive identity, and thus provided harsher sentence recommendations to the Spanish-speaking defendant.

Strength of evidence or how guilty a defendant is perceived to be can moderate judgments and create the black sheep effect (Gollwitzer \& Keller, 2010). Previous research has replicated the black sheep effect using various types of groups, such as university major, gender, membership in an organization, ethnicity, and the university attended by the participant (Gollwitzer \& Keller, 2010; Khan \& Lambert, 1998; Lewis \& Sherman, 2010; Marques et al., 1988; Van Prooijen \& Lam, 2007). 
It is important to keep in mind that the significant findings may be spurious and require replication before we can reach any solid conclusions. Future studies could build on the current study by adding an additional measure of language proficiency to measure English and Spanish proficiency in comparison to one another. For example, an item may ask participants to rate their proficiency in speaking, ranging from stronger in English, equal for both languages, and stronger in Spanish. This type of item would help isolate language dominance and perhaps prove to be a better predictor of sentence recommendations. Still, one problem with a self-report proficiency measure is the individual's ability to report an accurate score for language proficiency. Future studies should also administer a language proficiency test such as the Woodcock-Munoz Language Survey-Revised to have a more accurate report of language proficiency. Participants' self-reported language proficiency is highly variable, which creates an increased amount of error in the data. With a more precise tool to measure an individual's actual proficiency, instead of their perceived proficiency, I would have a more accurate assessment of language proficiency.

The results of the current study did not support the research hypotheses; however, this may be a good sign for Spanish-speaking defendants in the criminal justice system. Although language spoken by a witness or defendant may be an indicator for another social identity (i.e., ethnicity), jurors may not base their judgments solely on the language of testimony. Still, because the defendant was guilty in this case vignette, a black sheep effect was found that may affect in-group defendants. Additional studies, conducted in different parts of the country as well as with varying degrees of guilt or evidence against the defendant are necessary to further examine this hypothesis. The significant interaction between the defendant language and Spanish proficiency are highly tentative, and replication is warranted. Further, El Paso is located along the U.S./Mexico border, and has unique properties that make it different from other regions in 
the United States. Because most individuals who grow up in El Paso are exposed to both English and Spanish from an early age, they may not hold any biases toward Spanish speakers they encounter. 


\section{References}

Abwender, D. A., \& Hough, K. (2001). Interactive effects of characteristics of defendant and mock juror on U.S. participants' judgment and sentencing recommendations. The Journal of Social Psychology, 141(5), 603-615. doi: 10.1080/00224540109600574

Berk-Seligson, S. (1987). The intersection of testimony styles in interpreted judicial proceedings: Pragmatic alterations in Spanish testimony. Linguistics, 25(6), 1087-1126. doi: 10.1515/ Ling.1987.25.6.1087.//1987

Berk-Seligson, S. (1990). The bilingual courtroom. Chicago, IL: The University of Chicago Press.

Bradac, J. J. (1990). Language attitudes and impression formation. In H. Giles \& W. Robinson (Eds.), Handbook of language and social psychology (pp.387-412). Oxford England: John Wiley and Sons.

Brennan, E. M., \& Brennan, J. S. (1981). Accent scaling and language attitudes: Reactions to Mexican American English speech. Language and Speech, 24(3), 207-221. Retrieved from http://0-web.ebscohost.com.lib.utep.edu/ehost/detail?

vid=4\&hid=123\&sid=920df178-be6c-472d-b8ec-2414194b2fb2\%40sessionmgr 114 \&bdata=JnNpdGU9ZWhvc3QtbG12ZSZzY29wZT1zaXRl\#db=a9h\&AN=14091466

Brislin, R. W. (1986). The wording and translation of research instruments. In W. J. Lonner \& J. W. Berry (Eds.), Field methods in cross-cultural research, (pp. 137-164). Thousand Oaks, CA US: Sage Publications, Inc.

Bucolo, D. O., \& Cohn, E. S. (2010) Playing the race card: Making race salient in defense opening and closing statements. Legal and Criminological Psychology, 15, 293-303. doi: $10.1348135532508 X 400824$ 
Burnham, M., Telles, C., Karno, M., Hough, R., \& Escobar, J. (1987). Measurement of acculturation in a community population of Mexican Americans. Hispanic Journal of Behavioral Sciences, 9(2), 105-130. doi: 10.1177/07399863870092002

Court Interpreters Act, 28 U.S.C. $§ 1827$ et seq. (1978). Retrieved from GPO Access database: http://frwebgate.access.gpo.gov/cgi-bin/usc.cgi?ACTION=RETRIEVE $\&$ FILE $=\$$ xa $\$$ busc28. wais \&start=3157551\&SIZE $=22145 \&$ TYPE $=$ TEXT

Crowley, M. J., O’Callaghan, M. G., \& Ball, P. J. (1994). The juridical impact of psychological expert testimony in a simulated child sexual abuse trial. Law and Human Behavior, 18(1), 89-105. doi:10.1007/BF01499146

Dailey, R. M., Giles, H., \& Jansma, L. L. (2004). Language attitudes in an Anglo-Hispanic context: The role of the linguistic landscape. Language and Communication, 25(1), 2738. doi: 10.1016/j.langcom.2004.04.004

Dane, F. C. (1985). In search of reasonable doubt: A systematic examination of selected quantification approaches. Law And Human Behavior, 9(2), 141-158. doi:10.1007/BF01067048

De la Riva, E. M. (2012). Implicit attitudes of ethnicity and language: Evaluative and associative priming (Unpublished doctoral dissertation). The University of Texas at El Paso, El Paso, Texas.

Dhami, M. K. (2008). On measuring quantitative interpretations of reasonable doubt. Journal of Experimental Psychology: Applied, 14(4), 353-363. doi:10.1037/a0013344

DiDonato, T. E., Ullrich, J., \& Krueger, J. I. (2011). Social perception as induction and inference: An integrative model of intergroup differentiation, ingroup favoritism, and 
differential accuracy. Journal of Personality and Social Psychology, 100(1), 66-83. doi: $10.1037 / \mathrm{a} 0021051$

Downing, B. T., \& Holmer, S. (2007). Expert panel on community interpreter testing and certification. Retrieved from The Upper Midwest Translators and Interpreters Association website: http://www.umtia.org/ExpertPanel/Bill\%20Hewitt\%20\%20Expert\%20Panel.pdf

Duff, J. C. (2010). Annual Report of the Director. Retrieved from the Administrative Office of the United States Courts website: http://www.uscourts.gov/uscourts/FederalCourts/AnnualReport/2010/images/annualRepo rt2010.pdf

Erickson, B., Lind, E. A., Johnson, B. C., \& O’Barr, W. M. (1978). Speech style and impression formation in a court setting: The effects of "powerful" and "powerless" speech. Journal of Experimental Social Psychology, 14(3), 266-279. doi: 10.1016/0022-1031(78)90015-X

Espinoza, R. E., \& Willis Esqueda, C. (2008). Defendant and defense attorney characteristics and their effects on juror decision making and prejudice against Mexican Americans. Cultural Diversity and Ethnic Minority Psychology, 14(4), 364-371. doi: 10.1037/a0012767

ForsterLee, R., ForsterLee, L., Horowitz, I. A., \& King, E. (2006). The effects of defendant race, victim race, and juror gender on evidence processing in a murder trial. Behavioral Sciences \& the Law, 24(2), 179-198. doi:10.1002/bsl.675

Gabora, N. J., Spanos, N. P., \& Joab, A. (1993). The effects of complainant age and expert psychological testimony in a simulated child sexual abuse trial. Law And Human Behavior, 17(1), 103-119. doi:10.1007/BF01044540

Giles, H. (1973). Accent mobility: A model and some data. Anthropological Linguistics, 15, 
87-105.

Giles, H., Bourhis, R. Y., \& Taylor, D. M. (1977). Towards a theory of language in ethnic group relations. In H. Giles (Ed.). Language, ethnicity and intergroup relations (pp. 307-348). New York: Academic Press.

Gollwitzer, M., \& Keller, L. (2010). What you did only matters if you are one of us: Offenders' group membership moderates the effect of criminal history on punishment severity. Social Psychology, 41(1), 20-26. doi:10.1027/1864-9335/a000004

Horowitz, I. A. (1997). Reasonable doubt instructions: Commonsense justice and standard of proof. Psychology, Public Policy, And Law, 3(2-3), 285-302. doi:10.1037/1076-8971.3.23.285

Hosch, H. M., Daudistel, H. C., Holmes, M. D., \& Graves, J. B. (1991). Juror interviews. Unpublished raw data, University of Texas at El Paso.

Kerr, N. L., Hymers, R. W., Anderson, A. B., \& Weathers, J. E. (1995). Defendant-juror similarity and mock juror judgments. Law and Human Behavior, 19(6), 545-567. doi: 10.1007/BF01499374

Khan, S., \& Lambert, A. J. (1998). Ingroup favoritism versus black sheep effects in observations of informal conversations. Basic and Applied Social Psychology, 20(4), 263-269. doi:10.1207/s15324834basp2004_3

Lee, J. (2009). Interpreting inexplicit language during courtroom examination. Applied Linguistics, 30(1), 93-114. doi: 10.1093/applin/amn050

Lee, J. (2011). Translatability of speech style in court interpreting. The International Journal of Speech, Language, and the Law, 18(1), 1-33. doi: 10.1558/ijsll.v18i1.1

Lev-Ari, S., \& Keysar, B. (2010). Why don't we believe non-native speakers? The influence of 
accent on credibility. Journal of Experimental Social Psychology, 46(6), 1093-1096. doi: 10.1016/j.jesp.2010.05.025

Lewis, A. C., \& Sherman, S. J. (2010). Perceived entitativity and the black-sheep effect: When will we denigrate negative ingroup members?. The Journal of Social Psychology, 150(2), 211-225. doi:10.1080/00224540903366388

Licensed Court Interpreters Law, 2D Texas Dept. of Licensing $\$ 57.002$ (2011). Retrieved from: http://www.license.state.tx.us/court/lcilaw.htm

Lindemann, S. (2005) Who speaks “broken English”? U.S. undergraduates’ perceptions of nonnative English. International Journal of Applied Linguistics, 15(2), 187-212. doi: 10.1111/j.1473-4192.2005.00087.x

Lippi-Green, R. (1994). Accent, standard language ideology, and discriminatory pretext in the courts. Language in Society, 23(2), 163-198.

Marques, J. M., Yzerbyt, V. Y., \& Leyens, J. (1988). The 'Black Sheep Effect': Extremity of judgments towards ingroup members as a function of group identification. European Journal of Social Psychology, 18(1), 1-16. doi:10.1002/ejsp.2420180102

Mendoza, N. A., Hosch, H. M., Ponder, B. J., \& Carillo, V. (2000). Well...ah...: Hesitations And hedges as an influence on jurors' decisions. Journal of Applied Social Psychology, 30(12), 2610-2621. doi: 10.1111/j.1559-1816.2000.tb02452.x

Milroy, J., \& Milroy, L. (1999). Authority in language: Investigating standard English. [ebook collection EBSCOhost]. Retrieved from javascript:_doPostBack('ct100\$ct100\$Column1\$ Column1\$formatButtonsTop\$formatButtonRepeater\$ctl02\$linkButton',")

O’Barr, W. M. (1982) Linguistic evidence: Language, power, and strategy in the courtroom. New York, NY: Academic Press, Inc. 
Perez, D. A., Hosch, H. M., Ponder, B., \& Trejo, G. C. (1993). Ethnicity of defendants and jurors as influences on jury decisions. Journal of Applied Social Psychology, 23(15), 1249 1262. doi: 10.1111/j.1559-1816.1993.tb01031.x

Pozzulo, J. D., Dempsey, J., Maeder, E., \& Allen, L. (2010). The effects of victim gender, defendant gender, and defendant age on juror decision making. Criminal Justice and Behavior, 37(1), 47-63. doi: 10.1177//0093854809344173

Ryan, E. B., \& Carranza, M. A. (1975). Evaluative reactions of adolescents toward speakers of standard English and Mexican American accented English. Journal of Personality and Social Psychology, 31(5), 855-863. doi: 10.1037/h0076704

Schafer, J. L. (1997) Analysis of incomplete multivariate data. London: Chapman \& Hall.

Simon, R. J., \& Mahan, L. (1971). Quantifying burdens of proof: A view from the bench, the jury, and the classroom. Law and Society Review, 5(3), 319-330. Retrieved from: http://www.jstor.org/stable/3052837

Stephan, C. W., \& Stephan, W. G. (1986). Habla Ingles? The effects of language translation on simulated juror decisions. Journal of Applied Social Psychology, 16(7), 577-589.

Tajfel, H. (1970). Experiments in intergroup discrimination. Scientific American, 223, 96-102. doi: 10.1038/scientificamerican/170-96

Tajfel, H., \& Turner, J. C. (1979). An integrative theory of intergroup conflict. In W. G. Austin \& S. Worchel (Eds.), The social psychology of intergroup relations (pp. 33-47). Monterrey, CA: Brooks/Cole.

U.S. Bureau of Prisons (2011). Inmate Breakdown. Retrieved from http://www.bop.gov/news/quick.jsp

U.S. Census Bureau. (2009). American Community Survey. Retrieved from 
http://www.census.gov/acs/www/

U.S. Census Bureau. (2010). State and County QuickFacts. Retrieved from http://quickfacts.census.gov/qfd/states/00000.html

Van Prooijen, J., \& Lam, J. (2007). Retributive justice and social categorization: The perceived fairness of punishment depends on intergroup status. European Journal of Social Psychology, 37(6), 1244-1255. doi:10.1002/ejsp.421

Weitzer, R. \& Tuch, S. (2004) Rethinking minority attitudes toward the police. Final Technical Report-National Institute of Justice. Retrieved from https://www.ncjrs.gov/pdffiles/nij/grants/207145.pdf 
Table 1.1 Means, SDs, and 95\% CIs for variables in the model

\begin{tabular}{lcccc}
\hline IV's & M & SD & 95\% CI & Range \\
\hline Language Use & 40.25 & 10.14 & {$[39.04,41.45]$} & $11-55$ \\
English Proficiency & 36.60 & 7.51 & {$[35.71,37.49]$} & $4-40$ \\
Spanish Proficiency & 24.99 & 13.12 & {$[23.43,26.54]$} & $4-40$ \\
\hline DV's & & & & \\
Sentence in years & 7.25 & 5.38 & {$[6.61,7.89]$} & $5-99$ \\
Perception of Def. & 54.74 & 15.27 & {$[52.93,56.55]$} & $10-90$ \\
\hline
\end{tabular}

Table 1.2 Hierarchical regression model summary with defendant language and juror language use composite as predictors and sentence in years as dependent variable

\begin{tabular}{ccccc}
\hline Model & $\mathbf{R}^{\mathbf{2}}$ & Std. Error & $\mathbf{\Delta R}^{\mathbf{2}}$ & $\boldsymbol{p}$ \\
\hline 1 & .014 & 5.32 & .014 & .157 \\
2 & .021 & 5.33 & .007 & .566 \\
\hline
\end{tabular}

Table 1.3 Hierarchical regression model with individual predictors (dependent variable is sentence in years)

\begin{tabular}{lcccc}
\hline \multicolumn{1}{c}{ Model } & B & SE B & $\boldsymbol{p}$ & $\mathbf{9 5 \%}$ CI \\
\hline 1 (Constant) & 6.49 & .50 & .000 & {$[5.50,7.48]$} \\
Gender & 1.15 & .67 & .087 & {$[-.17,2.46]$} \\
Race/Ethn & .38 & .36 & .294 & {$[-.33,1.10]$} \\
\hline 2 (Constant) & 6.52 & .60 & .000 & {$[5.33,7.71]$} \\
Gender & 1.21 & .67 & .074 & {$[-.12,2.54]$} \\
Race/Ethn & .45 & .37 & .219 & {$[-.27,1.18]$} \\
Def. Lang & -.25 & .64 & .698 & {$[-1.52,1.02]$} \\
Mock Juror Lang. & .00 & .05 & .927 & {$[-.09, .10]$} \\
Interaction & .06 & .06 & .378 & {$[-.07, .18]$} \\
\hline
\end{tabular}


Table 2.1 Hierarchical regression model summary with defendant language and juror language use composite as predictors and perception of defendant composite as dependent variable

\begin{tabular}{ccccc}
\hline Model & $\mathbf{R}^{2}$ & Std. Error & $\mathbf{\Delta R}^{\mathbf{2}}$ & $\boldsymbol{p}$ \\
\hline 1 & .011 & 15.25 & .011 & .216 \\
2 & .015 & 15.30 & .004 & .797 \\
\hline
\end{tabular}

Table 2.2 Hierarchical regression with individual predictors (dependent variable is perception of defendant composite)

\begin{tabular}{lcccc}
\hline \multicolumn{1}{c}{ Model } & B & SE B & $\boldsymbol{p}$ & $\mathbf{9 5 \%}$ CI \\
\hline 1 (Constant) & 56.72 & 1.44 & .000 & {$[53.87,59.56]$} \\
Gender & -1.55 & 1.92 & .419 & {$[-5.32,2.22]$} \\
Race/Ethn & -1.69 & 1.04 & .105 & {$[-3.74, .35]$} \\
\hline 2 (Constant) & 55.96 & 1.74 & .000 & {$[52.54,59.38]$} \\
Gender & -1.71 & 1.94 & .379 & {$[-5.52,2.11]$} \\
Race/Ethn & -1.66 & 1.06 & .119 & {$[-3.74, .43]$} \\
Def. Lang & 1.61 & 1.85 & .384 & {$[-2.03,5.26]$} \\
Mock Juror Lang. & .06 & .14 & .651 & {$[-.21, .33]$} \\
Interaction & -.09 & .18 & .643 & {$[-.45, .28]$} \\
\hline
\end{tabular}


Table 3 Correlations between mock-juror language use, English, and Spanish proficiency composites.

\begin{tabular}{llll}
\hline & & A & B \\
\hline Mock Juror Lang. & 1 & $.495^{*}$ & $-.797^{*}$ \\
English Prof. (A) & & 1 & .114 \\
Spanish Prof. (B) & & & 1 \\
\hline
\end{tabular}


Table 4.1 Hierarchical regression model with English and Spanish proficiency composites as predictors (dependent variable is sentence in years)

\begin{tabular}{ccccc}
\hline Model & $\mathbf{R}^{\mathbf{2}}$ & Std. Error & $\mathbf{\Delta R}^{\mathbf{2}}$ & $\boldsymbol{p}$ \\
\hline 1 & .016 & 5.36 & .016 & .112 \\
2 & .053 & 5.31 & .037 & .107 \\
\hline
\end{tabular}

Table 4.2 Hierarchical regression with interaction of defendant language and Spanish proficiency composite (dependent variable is sentence in years)

\begin{tabular}{lcccc}
\hline & B & SE B & $\boldsymbol{p}$ & $\mathbf{9 5 \%}$ CI \\
\hline $\begin{array}{l}\text { Def.Lang. X } \\
\text { Spanish Prof. }\end{array}$ & -.104 & .00 & .047 & {$[-.21,-.00]$} \\
\hline
\end{tabular}

Table 4.3 Means of sentence in years

\begin{tabular}{lcccccc}
\hline & \multicolumn{3}{c}{$\begin{array}{c}\text { Spanish-speaking } \\
\text { Defendant }\end{array}$} & \multicolumn{2}{c}{$\begin{array}{c}\text { English-speaking } \\
\text { Defendant }\end{array}$} \\
\hline $\begin{array}{l}\text { Level of Spanish } \\
\text { Proficiency }\end{array}$ & M & SD & $\mathbf{9 5 \%}$ CI & M & SD & $\mathbf{9 5 \%}$ CI \\
\hline Low & 7.17 & 3.88 & {$[6.26,8.09]$} & 8.08 & 7.23 & {$[6.38,9.78]$} \\
High & 7.44 & 6.48 & {$[5.85,9.03]$} & 6.25 & 2.31 & {$[5.69,6.82]$} \\
\hline
\end{tabular}




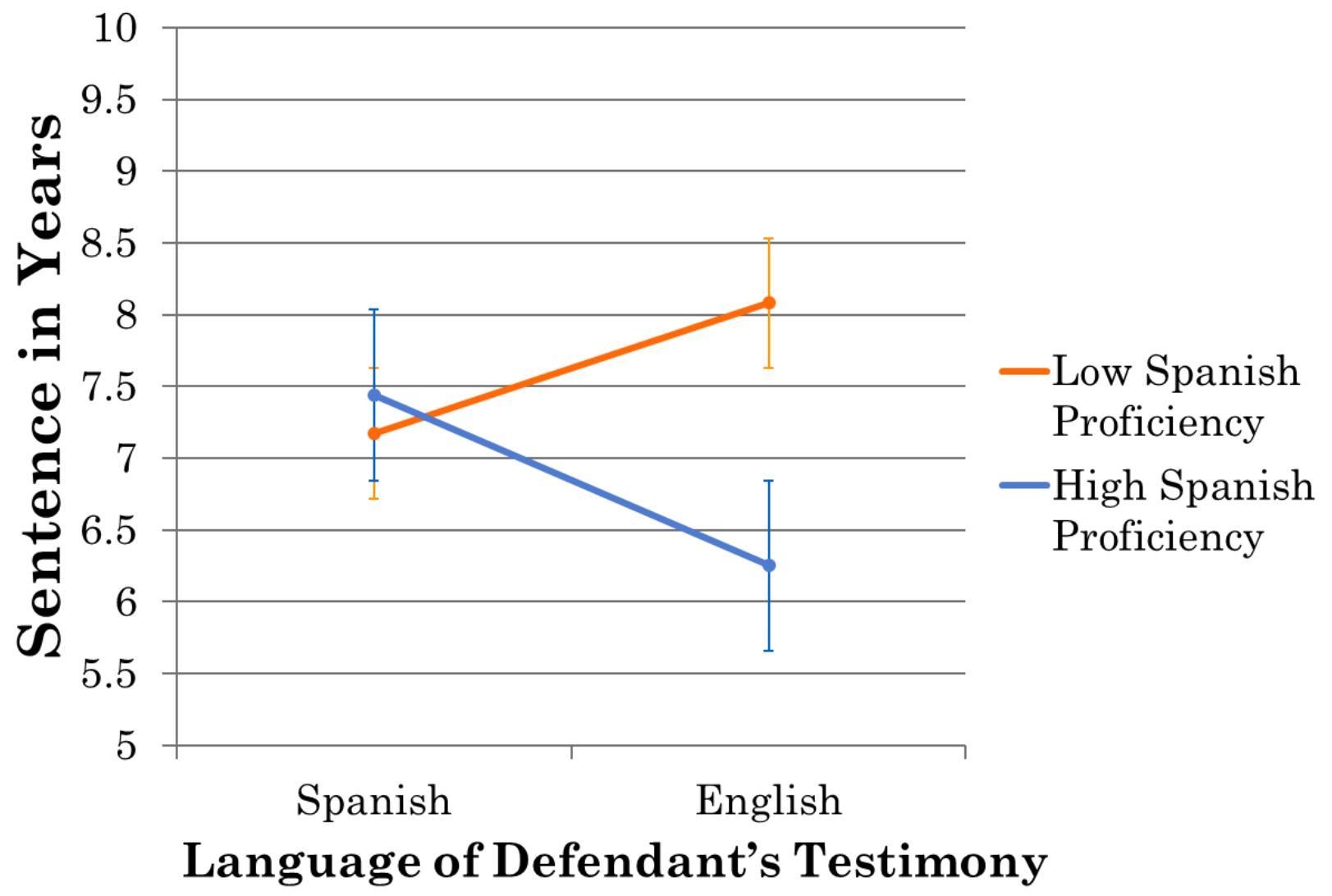

Figure 1 Interaction of language of testimony and Spanish proficiency on sentence in years 
Appendix A

University of Texas at El Paso (UTEP) Institutional Review Board
Informed Consent Form for Research Involving Human Subjects

Protocol Title: Juror Sentencing Recommendations

Principal Investigator: Victoria C. Estrada, B.A.

UTEP: Psychology Department

In this consent form, "you" always means the study subject. If you are a legally authorized representative (such as a parent or guardian), please remember that "you" refers to the study subject.

\section{Introduction}

You are being asked to take part voluntarily in the research project described below. Please take your time making a decision and feel free to discuss it with your friends and family. Before agreeing to take part in this research study, it is important that you read the consent form that describes the study. Please ask the study researcher or the study staff to explain any words or information that you do not clearly understand.

\section{Why is this study being done?}

You have been asked to take part in a research study to examine jury decision making. In this study, you will be asked to answer questions on a voir dire questionnaire, read a courtroom summary, and make decisions based on the evidence that is presented in the summary. You will also be asked to provide responses to additional questionnaires after reading the courtroom summary. Approximately 485 participants will be enrolling in this study at UTEP. You are being asked to be in the study because you are jury eligible over the age of 18. If you decide to enroll in this study, your involvement will last about an hour, and you will receive 1 credit hour of research involvement for your participation.

\section{What is involved in the study?}

If you agree to take part in this study, you will serve as a mock juror. You will be asked to answer a voir dire questionnaire and read a trial summary. Once you have read the materials, you will be asked to provide a sentence recommendation, and answer questions about the case and supporting material

\section{What are the risks and discomforts of the study?}

There is a risk of psychological discomfort to you from participating in this study. The amount of discomfort should not exceed anything you would experience in normal, everyday life. The courtroom summary contains a depiction of an individual being injured as a victim in an aggravated assault. In order to study juror's decisions, the background facts of a criminal case must be presented to the juror. The background facts of a criminal case may contain elements of violence that you may find discomforting. Please understand that while every measure has been taken to minimize depictions of violence in this research study, it would be impossible for the researchers to completely eliminate all violence in this research study. Please acknowledge 
that should you feel any discomfort in reading the courtroom summary, you may inform the experimenter and will be excused from participation in the experiment without losing any benefit that you might gain from having participated in the experiment. The experimenter will then debrief you as to the purpose of the study and should you desire to discuss any remaining feelings of discomfort, you will be directed to Counseling Services. The address for Counseling Services is:

University Counseling Center

202 Union Building West

Phone Number: 915-747-5302

Fax Number: 915-747-5393

Website: www.utep.edu/counsel/

Department Email: ucc@utep.edu

\section{What will happen if I am injured in this study?}

The University of Texas at El Paso and its affiliates do not offer to pay for or cover the cost of medical treatment for research related illness or injury. No funds have been set aside to pay or reimburse you in the event of such injury or illness. You will not give up any of your legal rights by signing this consent form. You should report any such injury to Victoria C. Estrada and to the UTEP Institutional Review Board (IRB) at (915-747-8841) or irb.orsp@utep.edu.

\section{Are there benefits to taking part in this study?}

There will be no direct benefits to you for taking part in this study. Through participation in this study, you may gain a clearer understanding of how psychological research is conducted. This research may help us to understand jury decision making and has important implications for the legal system.

\section{What other options are there?}

You have the option not to take part in this study. There will be no penalties involved if you choose not to take part in this study.

\section{Who is paying for this study?}

Funding for this study is provided by UTEP Department of Psychology.

\section{What are my costs?}

There are no direct costs. You will be responsible for travel to and from the research site and any other incidental expenses.

\section{Will I be paid to participate in this study?}

You will not be paid for taking part in this research study.

\section{What if I want to withdraw, or am asked to withdraw from this study?}

Taking part in this study is voluntary. You have the right to choose not to take part in this study. If you do not take part in the study, there will be no penalty. 
If you choose to take part, you have the right to stop at any time. However, we encourage you to talk to a member of the research group so that they know why you are leaving the study. If there are any new findings during the study that may affect whether you want to continue to take part, you will be told about them.

The researcher may decide to stop your participation without your permission, if he or she thinks that being in the study may cause you harm.

\section{Who do I call if I have questions or problems?}

If you have questions, you may contact the principal investigator, Victoria C. Estrada by phone at 747-8032 or by e-mail at vcestrada@miners.utep.edu. If you have any further questions that need to be discussed, you should contact Dr. Harmon M. Hosch, Professor of Psychology, at 747-6589.

If you have questions or concerns about your participation as a research subject, please contact the UTEP Institutional Review Board (IRB) at (915-747-8841) or irb.orsp@utep.edu.

\section{What about confidentiality?}

Your part in this study is confidential. None of the information you provide will identify you by name. All records will be stored in a locked filing cabinet in a locked office by the principal investigator.

\section{Mandatory reporting}

If information is revealed about child abuse or neglect, or potentially dangerous future behavior to others, the law requires that this information be reported to the proper authorities.

\section{Authorization Statement}

I have read each page of this paper about the study (or it was read to me). I know that being in this study is voluntary and I choose to be in this study. I know I can stop being in this study without penalty. I will get a copy of this consent form now and can get information on results of the study later if I wish.

Participant Name:

Date:

Participant Signature:

Time: 
Appendix B

\section{Voir Dire Questionnaire}

1. Age:

2. Gender: Female Male

3. Are you a U.S. Citizen? __ Yes _ No

4. Length of Residence in El Paso:

5. Race/Ethnicity:

White (non-Hispanic)

Hispanic

Black/African American

Asian

American Indian/ Native American

Pacific Islander

Other (please specify):

6. Licensed Driver: Y Yes No

State:

7. Registered Voter: __ Yes No

State:

8. Marital Status: __ Married _ N Never Married _ _ Divorced/Separated _ _ Widowed

9. Do you have any children? __ Yes _ _ No

If yes, how many children do you have?

If yes, how old are these children?

10. Your Occupation:

Employer:

11. Spouse's Occupation: Employer:

12. Last public/private school attended and grade completed/degree received: 
13. What is your college level?

Freshman

Sophomore

Junior

Senior

Graduate

Not sure

14. What is (was) the principal profession or vocation of your parents:

Father: Mother:

15. Your religious preference:

16. Have you actually served on a jury before? Yes No

If yes, how many times?

How many were: Civil Criminal Grand Jury

Was a verdict rendered? Yes No

17. Have you ever served in a court martial (a military trial)? Yes No

For Questions 18 and 19: The term, "Law Enforcement Officer" means any of the following or any other kind of sworn law enforcement officer: Police, Sheriff, Deputy, Constable, Highway Patrol, State Police, Prison Guard, F.B.I. Agent, Treasury Agent, Customs Agent, Postal Inspector, Immigration Agent, Border Patrolman, Drug Enforcement Agent, Military Police, Shore Patrol, Private Investigator, Security Guard, etc.

18. Are you now or have you ever been a law enforcement officer? Yes No

If yes, state what type:

When were you a law enforcement officer (yy-yy)?

19. Do you have a close friend or relative who is now or ever been a law enforcement officer? Yes__ No

If yes, state the nature of the relationship:

Type of law enforcement officer:

When the individual was (is) a law enforcement officer $(\mathbf{y y}-\mathbf{y y})$ :

20. Have you ever been a victim of a crime? Yes__ No 
If yes, state the nature of the crime (e.g. assault, burglary, etc.):

When it occurred (yyyy):

21. Has any close friend or relative been the victim of a crime? _ Yes No

If yes, state the nature of the crime (e.g. assault, burglary, etc.): When it occurred (yyyy):

22. Have you ever been a witness in a criminal case: ___ Yes _ _ No If yes, who were you a witness for? __ State/Prosecution __ Defendant If yes, state the nature of the crime: When it occurred (yyyy):

23. Have you ever been a party to a lawsuit? __ Yes __ No If yes, were you the: __Plaintiff __ Defendant

24. Have you ever made a claim for personal injuries? __ Yes __ No If yes, briefly describe the nature of the claim: 


\author{
Appendix C \\ [English-speaking Defendant]
}

Instructions

The state of Texas has a bifurcated trial, which means the guilt and sentencing phases of the case are separated into two parts. We have been approached by attorneys involved in a criminal trial to provide some empirical basis for how they should try the sentencing phase of the case. To help us with this phase, you are being asked to read through the following case summary, and provide your sentencing recommendations, as well as answers to additional questionnaires.

\title{
IN THE DISTRICT COURT OF EL PASO, TEXAS
}

No. $91 / 19-3112$

Filed 10/19/2008

\section{STATE OF TEXAS,}

vs.

\section{CARLOS RIVERA}

\section{Background Facts and Proceedings:}

On August 5, 2008, additional police units were dispatched to assist Officer Mario Hernandez, who was making a routine traffic stop on the 100 block of Santa Fe Street. At approximately 7:16 p.m., Officer Hernandez stopped a blue Dodge Neon traveling northbound on Santa Fe for speeding. The driver and owner of the vehicle was the defendant, Carlos Rivera. The officer obtained the defendant's license and insurance information, and informed the defendant that he had been traveling 46 miles per hour in a $35 \mathrm{mph}$ zone. Following police procedure, the officer began to check the defendant's records for any pending violations. The scan reported that the defendant had a warrant under his name due to unpaid tickets. The officer returned to the defendant, asked him to exit the vehicle, and began placing him under arrest, explaining the charge and reading him his Miranda rights.

The defendant began arguing with the police officer about the warrant. The police officer explained to the defendant that he checked the record twice and the warrant was a result of five outstanding traffic violations that had not been settled. The defendant began resisting the officer, and a struggle ensued. The officer attempted to restrain the defendant and place him in handcuffs, but the defendant managed to free one hand and began assaulting the officer, striking him repeatedly in the face. The 
officer was able to use his pepper spray to subdue the defendant. The defendant was overcome by the effects of the spray, which allowed the officer to restrain the defendant and request additional police units to his location. The defendant was placed under arrest and charged with $1^{\text {st }}$ degree felony aggravated assault. The officer was evaluated by the emergency medical technicians, and transported to a local hospital where he received treatment for a broken nose.

Court proceedings commenced on October 19, 2008. The prosecution called the victim, Officer Hernandez to testify as well as the officer who responded to the request for additional units. Both officers identified the defendant as the individual they encountered on August 5, 2008. The prosecution also submitted video recorded by the officer's dashboard camera, which captured the defendant's image and the events leading up to the arrest.

The defendant took the stand and was asked to give his account of the events leading up to his arrest. Speaking in his defense, Mr. Rivera gave the following testimony:

(Judge addresses Defense Attorney)

Judge: You may call your first witness, Council.

Defense Attorney: Thank you, Judge. I will call Carlos Rivera.

(Judge addresses Carlos Rivera)

Judge: Sir, if you would approach the witness stand.

(Defense Attorney addresses Carlos Rivera)

Defense Attorney: How are you doing, Mr. Rivera?

Carlos Rivera: I'm doing ok.

Defense Attorney: Would you please state your full name for the ladies and gentlemen of this jury?

Carlos Rivera: Yes. Carlos Rivera.

Defense Attorney: What do you do for a living?

Carlos Rivera: I work at a call center. I'm a customer service representative.

Defense Attorney: And how long have you been working in customer service?

Carlos Rivera: About four years.

Defense Attorney: Are you married? 
Carlos Rivera: No.

Defense Attorney: May I take you back to August $5^{\text {th }}, 2008$. Do you remember that day?

Carlos Rivera: Yes.

Defense Attorney: Can you describe for the ladies and gentlemen of this jury where you were around 7:00 that evening?

Carlos Rivera: I was driving home from work, and I was stopped by a police officer for speeding. He stopped me on Santa Fe Street.

Defense Attorney: What happened after the officer stopped you?

Carlos Rivera: The policeman told me that he checked my record and a warrant was under my name. I asked him what the warrant was for and he said because of tickets I didn't pay. I thought I had taken care of the tickets so I told him it was a mistake. He told me to get out of my car and started putting handcuffs on me, but it was a mistake. I tried to tell him that. He started getting rough when he tried to handcuff me, so I started to get free. I asked him to wait so I could explain, but he kept trying to handcuff me, and I thought he was being too rough.

The prosecution did establish that the warrant was valid and the defendant failed to take the required defensive driving courses or pay the fines related to the warrant. Again, the prosecution referred to the video recorded by the officer's dashboard camera, which captured the defendant's image and the events leading up to the arrest. A jury found the defendant guilty of $1^{\text {st }}$ degree aggravated assault. 
Instructions

[Spanish-speaking Defendant]

The state of Texas has a bifurcated trial, which means the guilt and sentencing phases of the case are separated into two parts. We have been approached by attorneys involved in a criminal trial to provide some empirical basis for how they should try the sentencing phase of the case. To help us with this phase, you are being asked to read through the following case summary, and provide your sentencing recommendations, as well as answers to additional questionnaires.

\section{IN THE DISTRICT COURT OF EL PASO, TEXAS}

No. $91 / 19-3112$

Filed 10/19/2008

\section{STATE OF TEXAS,}

VS.

\section{CARLOS RIVERA}

\section{Background Facts and Proceedings:}

On August 5, 2008, additional police units were dispatched to assist Officer Mario Hernandez, who was making a routine traffic stop on the 100 block of Santa Fe Street. At approximately 7:16 p.m., Officer Hernandez stopped a blue Dodge Neon traveling northbound on Santa Fe for speeding. The driver and owner of the vehicle was the defendant, Carlos Rivera, who only communicated in Spanish. The officer is a bilingual English-Spanish speaker, and was able to communicate with the defendant. He obtained the defendant's license and insurance information, and informed the defendant that he had been traveling 46 miles per hour in a $35 \mathrm{mph}$ zone. Following police procedure, the officer began to check the defendant's records for any pending violations. The scan reported that the defendant had a warrant under his name due to unpaid tickets. The officer returned to the defendant, asked him to exit the vehicle, and began placing him under arrest, explaining the charge and reading him his Miranda rights.

The defendant began arguing with the police officer about the warrant. The police officer explained to the defendant that he checked the record twice and the warrant was a result of five outstanding traffic violations that had not been settled. The defendant began resisting the officer, and a struggle ensued. The officer attempted to restrain the defendant and place him in handcuffs, but the defendant managed to free one hand and began assaulting the officer, striking him repeatedly in the face. The officer was able to use his pepper spray to subdue the defendant. The defendant was overcome by the effects of the spray, which allowed the officer to restrain the defendant 
and request additional police units to his location. The defendant was placed under arrest and charged with $1^{\text {st }}$ degree felony aggravated assault. The officer was evaluated by the emergency medical technicians, and transported to a local hospital where he received treatment for a broken nose.

Court proceedings commenced on October 19, 2008. A certified courtroom interpreter was provided to the defendant to translate courtroom proceedings. The prosecution called the victim, Officer Hernandez to testify as well as the officer who responded to the request for additional units. Both officers identified the defendant as the individual they encountered on August 5, 2008. The prosecution also submitted video recorded by the officer's dashboard camera, which captured the defendant's image and the events leading up to the arrest.

The defendant took the stand and was asked to give his account of the events leading up to his arrest. Speaking in his defense, Mr. Rivera gave the following testimony:

(Judge addresses Defense Attorney)

Judge: You may call your first witness, Council.

Defense Attorney: Thank you, Judge. I will call Carlos Rivera.

(Judge addresses Carlos Rivera)

Judge: Sir, if you would approach the witness stand.

(Interpreter instructs Carlos Rivera to take the stand)

(Defense Attorney addresses Carlos Rivera)

Defense Attorney: How are you doing, Mr. Rivera?

Carlos Rivera: Estoy bien.

Interpreter: I'm doing ok.

Defense Attorney: Would you please state your full name for the ladies and gentlemen of this jury?

Carlos Rivera: Sí. Carlos Rivera.

Interpreter: Yes. Carlos Rivera.

Defense Attorney: What do you do for a living?

Carlos Rivera: Trabajo en un centro de llamadas. Soy el representante de servicio al cliente. 
Interpreter: I work at a call center. I'm a customer service representative.

Defense Attorney: And how long have you been working in customer service?

Carlos Rivera: Como quatro años.

Interpreter: About four years.

Defense Attorney: Are you married?

Carlos Rivera: No.

Interpreter: No.

Defense Attorney: May I take you back to August $5^{\text {th }}, 2008$. Do you remember that day?

Carlos Rivera: Sí.

Interpreter: Yes.

Defense Attorney: Can you describe for the ladies and gentlemen of this jury where you were around 7:00 that evening?

Carlos Rivera: Iba manejando del trabajo hacía mi casa y fuí detenido por un oficial de policía por ir a exceso de velocidad. Me detuvo en la calle Santa Fe.

Interpreter: I was driving home from work, and I was stopped by a police officer for speeding. He stopped me on Santa Fe Street.

Defense Attorney: What happened after the officer stopped you?

Carlos Rivera: El oficial de policía me dijo que había checado mi historial y que una orden aparecía con mi nombre. Le pregunté de que se trataba la orden de y me dijo que era por multas que no había pagado. Yo pensé que ya había solucionado el problema con las multas y le dije que él estaba equivocado. Me dijo que bajara de mi carro y en ese momento empezó a ponerme las esposas pero era un error. Yo trate de decírsele. Empezó a ponerse brusco cuando trato de esposarme así que empecé a tratar de liberarme. Le pedi que parara para poder explicarle pero él siguió tratando de esposarme, y yo creo que estaba siendo demasiado brusco.

Interpreter: The policeman told me that he checked my record and a warrant was under my name. I asked him what the warrant was for and he said because of tickets I didn't pay. I thought I had taken care of the tickets so I told him it was a mistake. He told me to get out of my car and started putting handcuffs on me, but it was a mistake. I tried to tell him that. He started getting rough when he tried to handcuff me, so I started to get 
free. I asked him to wait so I could explain, but he kept trying to handcuff me, and I thought he was being too rough.

The prosecution did establish that the warrant was valid and the defendant failed to take the required defensive driving courses or pay the fines related to the warrant. Again, the prosecution referred to the video recorded by the officer's dashboard camera, which captured the defendant's image and the events leading up to the arrest. A jury found the defendant guilty of $1^{\text {st }}$ degree aggravated assault. 
Appendix D

\title{
IN THE DISTRICT COURT OF EL PASO, TEXAS
}

\section{THREE HUNDRED THIRTY-FOURTH JUDICIAL DISTRICT}

\author{
THE STATE OF TEXAS \\ V.
}

Carlos Rivera

It has been established beyond a reasonable doubt by the jury that the defendant is guilty of a first degree felony aggravated assault. Aggravated assault is defined as:

(1) causing serious bodily injury to another, including the person's spouse; or

(2) using or exhibiting a deadly weapon during the commission of the assault.

where a deadly weapon is defined as being:

(A) a firearm or anything manifestly designed, made, or adapted for the purpose of inflicting death or serious bodily injury; or

(B) anything that in the manner of its use or intended use is capable of causing death or serious bodily injury.

\section{SENTENCE}

When a defendant is found guilty, the State of Texas requires the jury to set a punishment within the following guidelines:

(1) *REQUIRED* a jail term for life or any term between $\mathbf{5}$ and 99 years

The defendant will serve a jail term of years

(2) an OPTIONAL fine not to exceed $\$ 10,000$

The defendant will receive a fine of dollars 


\section{Appendix E}

Please answer the following questions about the case summary.

1. What is the name of the defendant?

2. Why was the defendant stopped?

failure to stop

_broken brake light

_speeding

_expired inspection sticker

3. What was the defendant charged with?

$1_{\text {st }}$ Degree Felony

2nd Degree Felony

3 rd Degree Felony

State Jail Felony

Class A Misdemeanor

4. What is the name of the police officer who was assaulted?

5. What injury did the police officer receive?

_ broken arm

broken nose

_concussion

6. What language did the defendant speak?

English

Spanish

7. Based upon your review of this case, what is the likelihood that the defendant actually committed the crime with which he was charged? (Indicate your level of belief by writing a percentage from $0 \%$ to $100 \%$ ) $\%$ 
1. How intelligent is the defendant?

$\begin{array}{ccccccccc}1 & 2 & 3 & 4 & 5 & 6 & 7 & 8 & 9 \\ \text { Intelligent } & & & & & & & & \text { Unintelligent }\end{array}$

2. How friendly is the defendant?

$\begin{array}{ccccccccc}1 & 2 & 3 & 4 & 5 & 6 & 7 & 8 & 9 \\ \text { Friendly } & & & & & & & & \text { Unfriendly }\end{array}$

3. How trustworthy is the defendant?

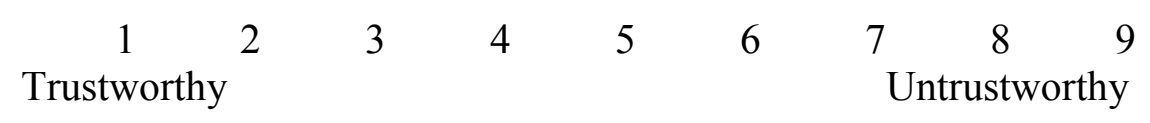

4. How interesting is the defendant?

$\begin{array}{ccccccccc}1 & 2 & 3 & 4 & 5 & 6 & 7 & 8 & 9 \\ \text { Interesting } & & & & & & & & \text { Uninteresting }\end{array}$

5. How considerate is the defendant?

$\begin{array}{cccccccc}1 & 2 & 3 & 4 & 5 & 6 & 7 & 8 \begin{array}{c}9 \\ \text { Considerate }\end{array} \\ & & & & & & \text { Inconsiderate }\end{array}$

6. How hard-working is the defendant?

$\begin{array}{ccccccccc}1 & 2 & 3 & 4 & 5 & 6 & 7 & 8 & 9 \\ \text { Hard-working } & & & & & & & \text { Lazy }\end{array}$

7. How competent is the defendant?

$\begin{array}{ccccccc}1 & 2 & 3 & 4 & 5 & 6 & 7 \underset{\text { Incompetent }}{9}\end{array}$

8. How likeable is the defendant?

$\begin{array}{ccccccccc}1 & 2 & 3 & 4 & 5 & 6 & 7 & 8 & 9 \\ \text { Likeable } & & & & & & & & \text { Not likeable }\end{array}$

9. How pleasant is the defendant?

$\begin{array}{ccccccccc}1 & 2 & 3 & 4 & 5 & 6 & 7 & 8 & 9 \\ \text { Pleasant } & & & & & & & & \text { Unpleasant }\end{array}$


10. How sophisticated is the defendant?

$\begin{array}{ccccccccc}1 & 2 & 3 & 4 & 5 & 6 & 7 & 8 & 9 \\ \text { Unsophisticated }\end{array}$




\section{Appendix F}

1. What American-born generation are you in your family?

First

_ Second

Third

Fourth

Fifth

2. What language do you speak?

$\begin{array}{ccccc}1 & 2 & 3 & 4 & 5 \\ \text { Spanish } & \text { Mostly } & \text { About the } & \text { Mostly } & \text { English } \\ \text { Only } & \text { Spanish } & \text { Same } & \text { English } & \text { Only }\end{array}$

3. What language do you prefer to speak?

$\begin{array}{ccccc}1 & 2 & 3 & 4 & 5 \\ \text { Spanish } & \text { Mostly } & \text { About the } & \text { Mostly } & \text { English } \\ \text { Only } & \text { Spanish } & \text { Same } & \text { English } & \text { Only }\end{array}$

4. What language do you use when speaking to your spouse?

$\begin{array}{ccccc}1 & 2 & 3 & 4 & 5 \\ \text { Spanish } & \text { Mostly } & \text { About the } & \text { Mostly } & \text { English } \\ \text { Only } & \text { Spanish } & \text { Same } & \text { English } & \text { Only }\end{array}$

5. What language do you use when speaking to your children?

$\begin{array}{ccccc}1 & 2 & 3 & 4 & 5 \\ \text { Spanish } & \text { Mostly } & \text { About the } & \text { Mostly } & \text { English } \\ \text { Only } & \text { Spanish } & \text { Same } & \text { English } & \text { Only }\end{array}$

6. What language do you use when speaking to your parents?

$\begin{array}{ccccc}1 & 2 & 3 & 4 & 5 \\ \text { Spanish } & \text { Mostly } & \text { About the } & \text { Mostly } & \text { English } \\ \text { Only } & \text { Spanish } & \text { Same } & \text { English } & \text { Only }\end{array}$

7. What language do you use when speaking to your coworkers?

$\begin{array}{ccccc}1 & 2 & 3 & 4 & 5 \\ \text { Spanish } & \text { Mostly } & \text { About the } & \text { Mostly } & \text { English } \\ \text { Only } & \text { Spanish } & \text { Same } & \text { English } & \text { Only }\end{array}$

8. What language do you use when speaking to your friends?

$\begin{array}{ccccc}1 & 2 & 3 & 4 & 5 \\ \text { Spanish } & \text { Mostly } & \text { About the } & \text { Mostly } & \text { English } \\ \text { Only } & \text { Spanish } & \text { Same } & \text { English } & \text { Only }\end{array}$

9. What language is used on the television programs that you usually watch?

$\begin{array}{ccccc}1 & 2 & 3 & 4 & 5 \\ \text { Spanish } & \text { Mostly } & \text { About the } & \text { Mostly } & \text { English }\end{array}$


$\begin{array}{llll}\text { Only Spanish } & \text { Same } & \text { Only }\end{array}$

10. What language is used on the radio programs that you usually listen to?

$\begin{array}{ccccc}1 & 2 & 3 & 4 & 5 \\ \text { Spanish } & \text { Mostly } & \text { About the } & \text { Mostly } & \text { English } \\ \text { Only } & \text { Spanish } & \text { Same } & \text { English } & \text { Only }\end{array}$

11. In what language do you think?

$\begin{array}{ccccc}1 & 2 & 3 & 4 & 5 \\ \text { Spanish } & \text { Mostly } & \text { About the } & \text { Mostly } & \text { English } \\ \text { Only } & \text { Spanish } & \text { Same } & \text { English } & \text { Only }\end{array}$

12. In what language do you read better?

$\begin{array}{ccccc}1 & 2 & 3 & 4 & 5 \\ \text { Spanish } & \text { Spanish } & \text { Both the } & \text { English } & \text { English } \\ \text { Only } & \text { Better } & \text { Same } & \text { Better } & \text { Only }\end{array}$

13. When reading for leisure, what language is the text?

$\begin{array}{ccccc}1 & 2 & 3 & 4 & 5 \\ \text { Spanish } & \text { Spanish } & \text { Both the } & \text { English } & \text { English } \\ \text { Only } & \text { Mostly } & \text { Same } & \text { Mostly } & \text { Only }\end{array}$

14. In what language do you write better?

$\begin{array}{ccccc}1 & 2 & 3 & 4 & 5 \\ \text { Spanish } & \text { Spanish } & \text { Both the } & \text { English } & \text { English } \\ \text { Only } & \text { Better } & \text { Same } & \text { Better } & \text { Only }\end{array}$

15. What is the ethnicity of the people in your neighborhood?

$\begin{array}{ccccc}1 & 2 & 3 & 4 & 5 \\ \text { All } & \text { Most } & \text { Half } & \text { Few } & \text { None } \\ \text { Hispanic } & \text { Hispanic } & \text { Hispanic } & \text { Hispanic } & \text { Hispanic }\end{array}$

16. What is the ethnicity of your coworkers?

$\begin{array}{ccccc}1 & 2 & 3 & 4 & 5 \\ \text { All } & \text { Most } & \text { Half } & \text { Few } & \text { None } \\ \text { Hispanic } & \text { Hispanic } & \text { Hispanic } & \text { Hispanic } & \text { Hispanic }\end{array}$

17. What is the ethnicity of your close friends?

\begin{tabular}{|c|c|c|c|c|}
\hline 1 & 2 & 3 & 4 & 5 \\
\hline All & Most & Half & Few & None \\
\hline Hispanic & Hispanic & Hispanic & Hispanic & Hispanic \\
\hline \multicolumn{5}{|c|}{ What proportion of the time do you eat Hispanic foods? } \\
\hline 1 & 2 & 3 & 4 & 5 \\
\hline $\begin{array}{l}\text { All of } \\
\text { the time }\end{array}$ & $\begin{array}{l}\text { Most of } \\
\text { the time }\end{array}$ & $\begin{array}{l}\text { Half of } \\
\text { the time }\end{array}$ & Sometimes & Never \\
\hline
\end{tabular}


19. What proportion of the time do you listen to Latin music?

$\begin{array}{ccccc}1 & 2 & 3 & 4 & 5 \\ \text { All of } & \text { Most of } & \text { Half of } & \text { Sometimes } & \text { Never } \\ \text { the time } & \text { the time } & \text { the time } & & \end{array}$

20. What proportion of the time do you celebrate in Hispanic tradition?

$\begin{array}{ccccc}1 & 2 & 3 & 4 & 5 \\ \text { All of } & \text { Most of } & \text { Half of } & \text { Sometimes } & \text { Never } \\ \text { the time } & \text { the time } & \text { the time } & & \end{array}$

21. What is the ethnicity of the people in your leisure-time social environment?

$\begin{array}{ccccc}1 & 2 & 3 & 4 & 5 \\ \text { All } & \text { Most } & \text { Half } & \text { Few } & \text { None } \\ \text { Hispanic } & \text { Hispanic } & \text { Hispanic } & \text { Hispanic } & \text { Hispanic }\end{array}$

22. What is your ethnic background?

- Mexican

- Chicano

- Mexican American

_ Latin American, other Hispanic American (please specify):

_ Anglo American or other

23. What is your mother's ethnic background?

Mexican

- Chicano

- Mexican American

_ Latin American, other Hispanic American (please specify):

_ Anglo American or other

24. What is your father's ethnic background?

- Mexican

- Chicano

Mexican American

_ Latin American, other Hispanic American (please specify):

Anglo American or other

25. In what country did you spend your childhood?

U.S.

_ Other (please specify):

26. What proportion of your life have you lived in the United States versus a Hispanic country?

$\begin{array}{cccc}1 & 2 & 3 & 4 \\ \begin{array}{c}\text { Mostly Hispanic, } \\ \text { part U.S. }\end{array} & \text { Equal } & \text { Mostly U.S., } & \text { U.S. only } \\ & & \text { part Hispanic } & \end{array}$




\section{Appendix G}

1. Do you consider yourself to be bilingual in English and Spanish?

2. What language do you consider your stronger language overall?

Yes

No

3. What language did you being to learn first as a child?

English

English

Other

3a. At what age did you being to learn English?

3b. At what age did you begin to learn Spanish?

3c. Do you sometimes mix English and Spanish?

Yes Spanish If yes, at what age did you begin to mix them?

4. Do you speak or have you studied any other languages?

Language:

Language:

Language: Age learned Age learned Age learned El Paso Ciudad Juárez Spanish

5. Where do you live now?

\begin{tabular}{ll}
\hline Fluent? Yes & No \\
Fluent? Yes & No \\
Fluent? Yes & No
\end{tabular}

5a. How long have you lived in Mexico or another Spanish-speaking country? _ years _ months

5b. How long have you lived in the U.S.? years months

How long have you lived in El Paso or another bilingual city? years months

How long have you lived in a primarily English-speaking city? years months

5c. What years of your education were in English? (Circle all years that apply)
Grades:
K 1
$\begin{array}{llllllllll}4 & 5 & 6 & 7 & 8 & 9 & 10 & 11 & 12\end{array}$
University: $1 \begin{array}{llllll}1 & 2 & 3 & 4 & 5 & 6\end{array}$

$5 \mathrm{~d}$. What years of your education were in Spanish? (Circle all years that apply)

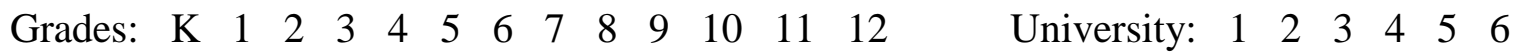
(Note: circle for both English and Spanish if you were in a bilingual education program)

6. Indicate for yourself and your relatives in what country they were born and what their first language was.

\begin{tabular}{|c|c|}
\hline Person & Country of Birth \\
\hline Self & U.S. Mex. Other NS \\
\hline Mother & U.S. Mex. Other NS \\
\hline Father & U.S. Mex. Other NS \\
\hline $\begin{array}{l}\text { Maternal } \\
\text { Grandmother }\end{array}$ & U.S. Mex. Other NS \\
\hline
\end{tabular}

\begin{tabular}{|ccccc|}
\hline \multicolumn{5}{|c|}{ First Language } \\
\hline Eng & Span & Both & Other & DK \\
\hline Eng & Span & Both & Other & DK \\
\hline Eng & Span & Both & Other & DK \\
\hline Eng & Span & Both & Other & DK \\
& & & & \\
\hline
\end{tabular}




\begin{tabular}{|l|lll|}
\hline $\begin{array}{l}\text { Maternal } \\
\text { Grandfather }\end{array}$ & U.S. Mex. Other NS \\
\hline $\begin{array}{l}\text { Paternal } \\
\text { Grandmother }\end{array}$ & U.S. Mex. Other NS \\
\hline $\begin{array}{l}\text { Paternal } \\
\text { Grandfather }\end{array}$ & U.S. Mex. Other NS \\
\hline
\end{tabular}

\begin{tabular}{|cll|}
\hline Eng Span Both Other DK \\
\hline Eng Span Both Oth DK \\
\hline Eng Span Both Other DK \\
\hline
\end{tabular}

*If you marked Other for any ítem above, please indicate what country or what language. $*$ DK $=$ Don't Know

Please circle the number that best indicates your proficiency level on the following English language skills:

\section{English reading}

Not Literate

Very Literate

$\begin{array}{llllllllll}1 & 2 & 3 & 4 & 5 & 6 & 7 & 8 & 9 & 10\end{array}$

\section{English writing}

Not literate

$\begin{array}{llllllllll}1 & 2 & 3 & 4 & 5 & 6 & 7 & 8 & 9 & 10\end{array}$

\section{English speaking}

Not Fluent

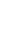

\section{$\begin{array}{cccc}1 & 2 & 3 & 4 \\ \text { sh speech comprehension }\end{array}$}

Unable to understand

conversation

$\begin{array}{llllllllll}\text { perfectly } & \\ 1 & 2 & 3 & 4 & 5 & 6 & 7 & 8 & 9 & 10\end{array}$

Please circle the number that best indicates your proficiency level on the following Spanish language skills:

\section{Spanish reading}

Not Literate

Very Literate

$\begin{array}{lllllllllll}1 & 2 & 3 & 4 & 5 & 6 & 7 & 8 & 9 & 10\end{array}$

\section{Spanish writing}

Not Literate

Very Literate

$\begin{array}{llllllllll}1 & 2 & 3 & 4 & 5 & 6 & 7 & 8 & 9 & 10\end{array}$




\section{Spanish speaking}

Not Fluent

$\begin{array}{llll}1 & 2 & 3 & 4\end{array}$

\section{Spanish speech comprehension}

Unable to understand

conversation
12
3
4
5
6
7

8

Very Fluent

Please rate how well you translate from Spanish to English:

Unable to translate
12

3
4
5
6
7

8
Able to translate perfectly
10

Able to understand conversation perfectly 10

Please rate how well you translate from English to Spanish:

Unable to translate

Able to translate

$\begin{array}{cccccccccc}1 & 2 & 3 & 4 & 5 & 6 & 7 & 8 & 9 & 10\end{array}$

\section{Frequency of Usage}

1. How often do you communicate in English?

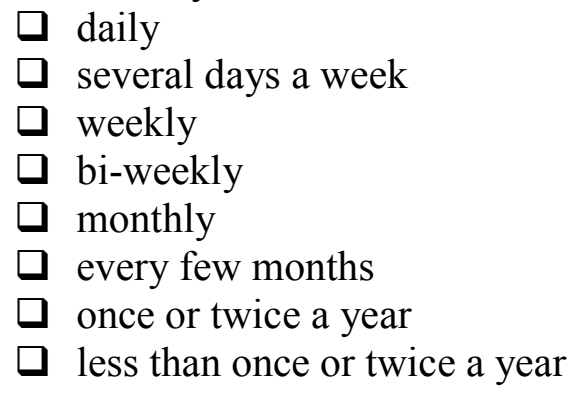

2. How often do you communicate in Spanish?

$\square$ daily

$\square$ several days a week

$\square$ weekly

$\square$ bi-weekly

$\square$ monthly

$\square$ every few months

$\square$ once or twice a year

$\square$ less than once or twice a year 
1. Over the past month, what percentage of your speaking was in

English?

Spanish?

Mixed English and Spanish?

Other Languages? (please specify

2. Over the past month, what percentage of the time was language you listened to in

English?

Spanish?

Mixed English and Spanish?

Other Languages? (please specify

3. Over the past month, what percentage of your reading was in

English?

Spanish?

Mixed English and Spanish?

Other Languages? (please specify

4. Over the past month, what percentage of your writing was in

English?

Spanish?

Mixed English and Spanish?

Other Languages? (please specify

\section{Context of Usage}

1. Please rate how much you use English and Spanish in the following contexts (please circle):

\begin{tabular}{|l|c|c|c|c|c|}
\hline & $\begin{array}{c}\text { Only } \\
\text { English }\end{array}$ & $\begin{array}{c}\text { Mostly } \\
\text { English }\end{array}$ & $\begin{array}{c}\text { Equally } \\
\text { English \& } \\
\text { Spanish }\end{array}$ & $\begin{array}{c}\text { Mostly } \\
\text { Spanish }\end{array}$ & $\begin{array}{c}\text { Only } \\
\text { Spanish }\end{array}$ \\
\hline Home/with Family & 1 & 2 & 3 & 4 & 5 \\
\hline \multicolumn{1}{|c|}{ With Parents } & 1 & 2 & 3 & 4 & 5 \\
\hline \multicolumn{1}{|c|}{ With Siblings } & 1 & 2 & 3 & 4 & 5 \\
\hline School/University & 1 & 2 & 3 & 4 & 5 \\
\hline At Work & 1 & 2 & 3 & 4 & 5 \\
\hline With Friends & 1 & 2 & 3 & 4 & 5 \\
\hline $\begin{array}{l}\text { Viewing or Listening to } \\
\text { Media (TV, radio, music, } \\
\text { internet, newspaper, } \\
\text { magazines, books) }\end{array}$ & 1 & 2 & 3 & 4 & 5 \\
\hline Thinking Aloud or Silently & 1 & 2 & 3 & 4 & 5 \\
\hline Dreaming & & 2 & 3 & & \\
\hline
\end{tabular}




\section{Appendix H}

1. In general, how satisfied or dissatisfied are you with the police department in your neighborhood?

$\begin{array}{cccc}1 & 2 & 3 & 4 \\ \text { Very } & \text { Somewhat } & \text { Somewhat } & \text { Very }\end{array}$

Satisfied Satisfied Dissatisfied Dissatisfied

2. How often do you think police officers stop people on the streets of your neighborhood without good reason?

$\begin{array}{cccc}1 & 2 & 3 & 4 \\ \text { Very } & \text { Fairly } & \text { On } & \text { Never }\end{array}$

Often Often Occasion

3. When police officers use force against people, how often do you think they use excessive force (in other words, more force than is necessary under the circumstances) against people in your neighborhood?

$\begin{array}{cccc}1 & 2 & 3 & 4 \\ \text { Very } & \text { Fairly } & \text { On } & \text { Never } \\ \text { Often } & \text { Often } & \text { Occasion } & \end{array}$

4. How common do you think corruption (such as taking bribes, involvement in drug trade) is in your city's police department?
1
Very
2
Fairly
Common
Not Very
Common
4
Not At
Common
All Common

Common

5. Have you ever been stopped by police on the street without good reason in your neighborhood/city?

Yes

- No

6. Have the police ever used insulting language towards you in your neighborhood/city?

_ Yes

No

7. Have police ever used excessive force against you in your neighborhood/city?

Y Yes

- No

8. Have you ever seen a police officer engage in any corrupt activities in your

neighborhood/city?

Yes

No 
9. Has anyone else in your household ever been stopped by police without good reason in your neighborhood/city?

Yes

No

10. Have the police ever used insulting language toward anyone else in your household in your neighborhood/city?

Yes

- No

11. Have police ever used excessive force against anyone else in your household in your neighborhood/city?

Yes

No

12. Do you think the police in your city/neighborhood treat whites and blacks equally?
Whites worse
Equal
Blacks worse

13. Do you think the police in your city/neighborhood treat whites and Hispanics equally? Whites worse __ Equal__ Hispanics worse

14. Do you think the police in your city treat blacks and Hispanics equally?
Hispanics worse
Equal
Blacks worse

15. In general in the United States, do you think that police services in white neighborhoods are better, worse, or about the same as in black neighborhoods?

Worse in white __ About the same Better in white

16. In general in the United States, do you think that police services in white neighborhoods are better, worse, or about the same as in Hispanic neighborhoods?

Worse in white __ About the same __ Better in white

17. In general in the United States, do you think that police services in black neighborhoods are better, worse, or about the same as in Hispanic neighborhoods?

Worse in black ___ About the same___Better in black

18. How common do you think racial or ethnic prejudice is among police officers throughout the United States?

$$
1
$$

Very

Uncommon
2

Somewhat

Uncommon
3

Somewhat

Common
4

Very

Common 
19. How common do you think racial or ethnic prejudice is among officers who work in your neighborhood/city?

12

Very

Uncommon
Somewhat

Uncommon
3
Somewhat

Common
4
Very

Common

20. There have been reports that some police officers stop drivers from certain racial groups because they think members of these groups are more likely to commit crimes. This is known as "racial profiling." Do you approve or disapprove of the use of this practice? Approve _Disapprove

21. If you answered "disapprove", suppose that studies showed that racial profiling helps to catch criminals. If this is true, would you still disapprove of racial profiling? Yes

No

22. If you answered "Approve", what if studies showed that racial profiling does not help to catch criminals? Would you still approve of racial profiling?

Yes

- No

23. Do you think racial profiling is widespread in the United States?

Yes

No

24. Do you think racial profiling is widespread in your neighborhood/city?

Yes

No

25. Do you think that black drivers are more likely to be stopped by the police than white drivers for the same types of violations?

Yes

No

26. Do you think that Hispanic drivers are more likely to be stopped by the police than white drivers for the same types of violations?

Yes

No

27. Do you think that black drivers are more likely to be stopped by the police than Hispanic drivers for the same types of violations?

Yes

- No 
28. Have you ever felt you were treated unfairly by the police specifically because of your race/ethnicity?

Yes

No

29. Has anyone else in your household ever felt that they were treated unfairly by the police specifically because of their race/ethnicity?

Yes

No

30. Have you ever felt that you were stopped by the police just because of your race or ethnic background?

Yes

- No

31. Has anyone else in your household ever felt that they were stopped by the police just because of their race or ethnic background?

Yes

- No

32. Do you think that minorities should be given preferences in hiring so that a police department will have a similar racial makeup to the racial makeup of that city?

Yes

- No

33. Which of the following do you think would improve either the police department or police services in your city?

...Hire more minority officers 1

Improve Improve

A Lot

Somewhat

3

Not Improve

Much

...Assign more minority officers to minority neighborhoods 1

Improve

A Lot
2

Improve

Somewhat
3

Not Improve

Much
4

Not Improve

At All
4

Not Improve

At All 


\section{Appendix I}

\section{Debriefing Form}

The purpose of this research project is to examine the effects of language use on juror sentencing recommendations. Your participation will help us gain a better understanding about extra-legal factors that influence juror/jury decision-making. You have the option not to take part in this study, and there will be no penalties involved if you choose not to take part in this study. Should you desire to discuss any remaining feelings of discomfort, you may contact the University Counseling Center at (915)747-5302. These services are free to UTEP students.

If you have questions about this study, you may contact the principal investigator, Victoria C. Estrada by phone at 747-8032 or by e-mail at vcestrada@miners.utep.edu. If you have any further questions that need to be discussed, you should contact Dr. Harmon M. Hosch, Professor of Psychology, at 747-6589.

If you have questions or concerns about your participation as a research subject, please contact the UTEP Institutional Review Board (IRB) at (915-747-8841) or irb.orsp@utep.edu.

Thank you for your participation in this study. 


\section{Curriculum Vita}

Victoria C. Estrada was born June 30, 1986 in El Paso, Texas. The second daughter of Irma and David Estrada, she graduated from Fabens High School in Fabens, Texas in 2004. In August of 2004, she attended The University of Texas at El Paso (UTEP) with a Dorothy J. Lovett Scholarship award. She completed her Bachelor of Arts in Psychology in the fall of 2009 and graduated Cum Laude. In the fall of 2010, she was accepted to the Master of Arts Experimental Psychology program at UTEP under the supervision of Dr. Harmon M. Hosch, where she worked as a teaching assistant and research assistant for the FBI/High Value Detainee Interrogation Group (HIG). In 2012, she gave an oral presentation of her research on alibi believability and juror decision-making at the Annual American Psychology-Law Society Conference in San Juan, Puerto Rico.

She will continue her education in the fall of 2012 at the University of Wyoming, Laramie, where she will pursue a Ph.D. in legal psychology. Her research interests include jury decision-making, alibi witnesses, and deception detection.

Permanent address: Victoria C. Estrada

825 Delhi Dr.

Socorro, Texas 79927

This thesis/dissertation was typed by Victoria C. Estrada, B.A. 